\title{
Authorized Limits for Fernald Copper Ingots
}

N. Frink, ${ }^{*}$ S. Kamboj, J. Hensley, and S.-Y. Chen

prepared by Environmental Assessment Division,

Argonne National Laboratory, 9700 South Cass Avenue, Argonne, Illinois 60439

September 1997

prepared for

U.S. Department of Energy, Ohio Field Office, Miamisburg, Ohio,

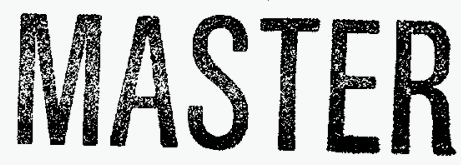
and Fernald Site Office, Fernald, Ohio

*Frink is affiliated with Trinity Environmental Systems, Inc., Cincinnati, Ohio. 
Gy

This report is printed on recycled paper. 


\section{DISCLAIMER}

This report was prepared as an account of work sponsored by an agency of the United States Government. Neither the United States Government nor any agency thereof, nor any of their employees, makes any warranty, express or implied, or assumes any legal liability or responsibility for the accuracy, completeness, or usefulness of any information, apparatus, product, or process disclosed, or represents that its use would not infringe privately owned rights. Reference herein to any specific commercial product, process, or service by trade name, trademark, manufacturer, or otherwise does not necessarily constitute or imply its endorsement, recommendation, or favoring by the United States Government or any agency thereof. The views and opinions of authors expressed herein do not necessarily state or reflect those of the United States Government or any agency thereof. 


\section{DISCLAMIER}

Portions of this document may be illegible in electronic image products. Images are produced from the best available original document. 


\section{CONTENTS}

ACKNOWLEDGMENTS

NOTATION

vii

SUMMARY

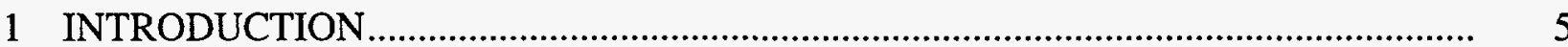

2 REGULATORY FRAMEWORK AND POLICY CONSIDERATIONS ........................ 7

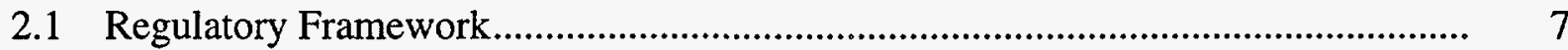

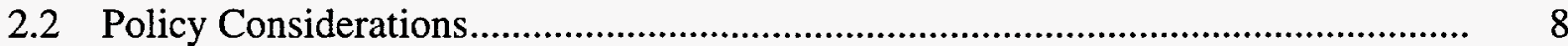

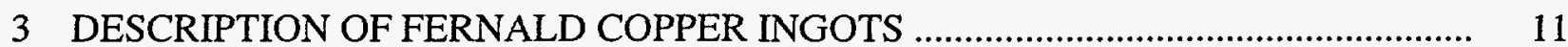

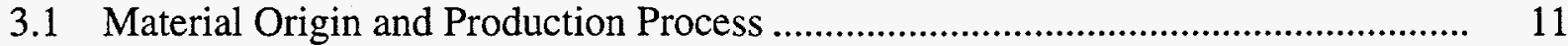

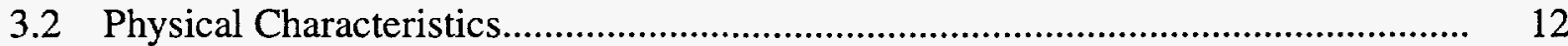

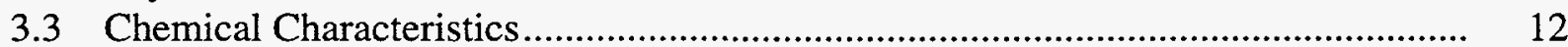

3.4 Radiological Characteristics......................................................................... 12

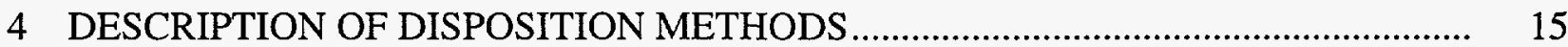

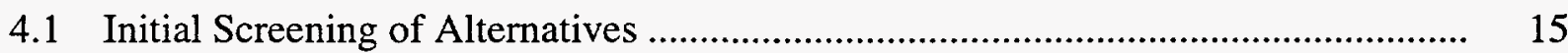

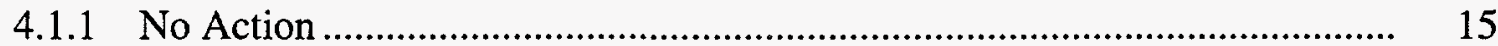

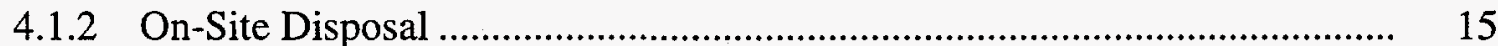

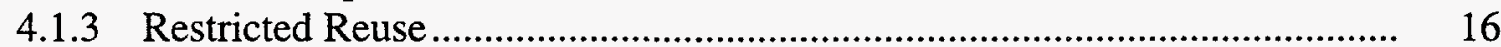

4.1.4 Decontamination Prior to Release ....................................................... 17

4.2 Unrestricted Release for Recycle ................................................................... 17

4.2.1 Secondary Copper and Product Manufacturing ........................................ 18

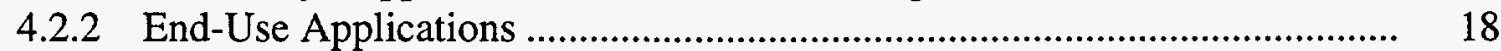

4.3 Disposal at Off-Site Low-Level-Waste Facility .............................................. 21

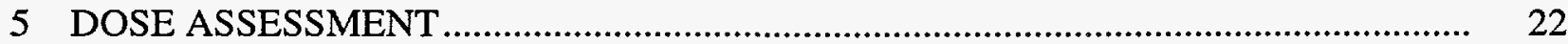

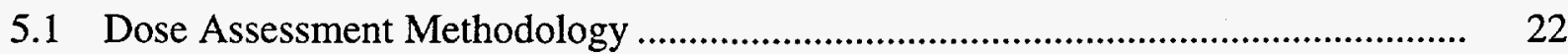

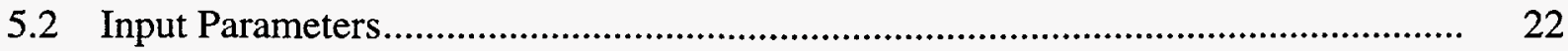

5.3 Dose Estimates for Release Scenarios.................................................................. 24

6 COST ANALYSIS

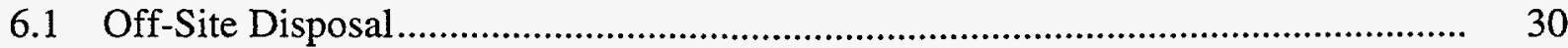

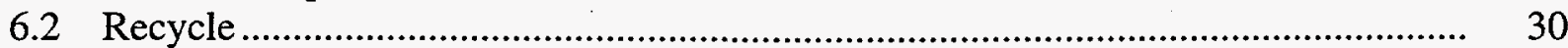




\section{CONTENTS (Cont.)}

7 ALARA ANALYSIS

8 ADDITIONAL FACTORS

8.1 Schedule Impacts

8.2 Local Economic Impacts

8.3 Institutional Preferences

8.4 Local Social Preference

8.5 Environmental Impacts

8.5.1 Land Disturbance

8.5.2 Water Quality Degradation .................................................................. 37

8.5.3 Air Quality Degradation ............................................................................. 37

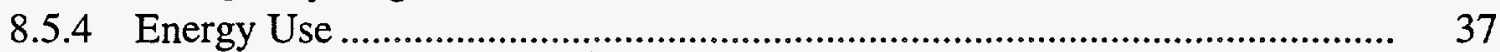

$9 \quad$ PREPARATION PRIOR TO RELEASE ....................................................................... 39

9.1 DOE Property Management Procedures ................................................................ 39

9.2 Surface Treatment, Decontamination, and Packaging for Transport ........................ 39

10 SURVEY AND ANALYSIS METHODS .................................................................... 40

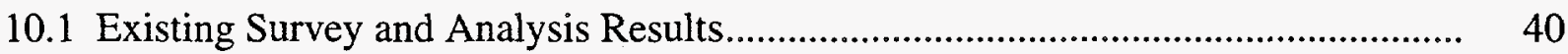

10.2 Quality Assurance and Quality Control .............................................................. 40

10.3 Survey and Analysis Prior to Release .................................................................. 41

10.4 Survey and Analysis Documentation ................................................................ 41

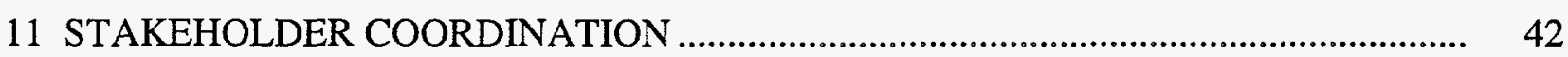

12 REFERENCES

APPENDIX: Overview of Secondary Copper Industry ....................................................... 45

\section{FIGURES}

S.1 Comparison of Dose with Existing Release Standards and Dose Limits........................ 3

1 Pathways for Worker and Public Exposures during Copper Ingot Processing ............... 23

2 Cost for Fernald Ingot Disposition Alternatives .............................................................. 31

A.1 Flow of Copper Scrap and Refined Copper in the United States.................................. 51 


\section{TABLES}

S.1 Proposed Authorized Limits for Release of Fernald Copper Ingots ................................. 2

1 Crosswalk among Development Document Sections, Handbook Guidance, and Fernald Decision Methodology ............................................................................ 9

2 Physical Attributes of Remaining Fernald Copper Ingots .............................................. 12

3 Chemical Attributes of Fernald Copper Ingots ………....................................................

4 Activity Concentration of Radionuclides in Fernald Copper Ingots................................ 14

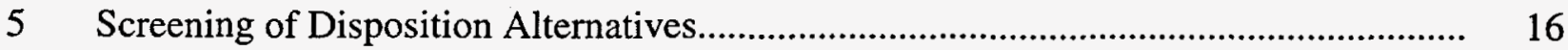

$6 \quad$ Product Distribution Scenarios................................................................................ 19

$7 \quad$ Initial Radionuclide Concentrations in Fernald Copper................................................... 23

$8 \quad$ Partitioning Factors for Fire Refining of Copper ………............................................. 24

$9 \quad$ Worker Exposure Scenarios and Parameters................................................................. 25

10 Public End-Use Exposure Scenarios and Parameters..................................................... 26

11 Individual and Collective Doses in Worker Scenarios

for Processing Fernald Copper Ingots

12 Individual, Collective, and Cumulative Doses for End-Use Product

Scenarios for Fernald Copper Ingots......................................................................... 28

13 Basis of Estimate for Disposition Alternative Costs....................................................... 29

14 Decision Summary Matrix ……………………...............................................

A.1 U.S. Consumption of Copper Products by Major End-Use Market in 1994................... 48

A.2 U.S. Supply of Products from Wire Mills, Brass Mills, Foundries, and Powder Plants .................................................................................... 50

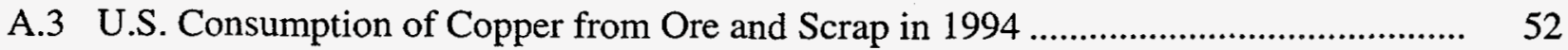

A.4 Consumption of Scrap Copper at U.S. Processing Facilities by Grade .......................... 53 


\section{ACKNOWLEDGMENTS}

This report was made possible through cooperative efforts of several U.S. Department of Energy (DOE) Program Offices (EM-43, EM-77, and EH-41), the Ohio Field Office, and the Fernald Site Office. In March 1997, EM-43, working with EH-41, published the Draft Handbook for Controlling Release for Reuse or Recycle of Property Containing Residual Radioactive Material. In anticipation of the handbook, the Ohio Field Office requested funding to support a case study implementing the new guidance. The project was funded by EM-77 as one of seven interrelated tasks designed to enhance site-level implementation of pollution prevention, reuse, and recycling initiatives. The Fernald Site Office took the lead role on the project, providing oversight and direction for project activities.

The project benefited greatly from the insights and comments provided by DOE personnel, including Pete Yerace (DOE-FN), Don Hodge (DOE-OH), Bob Fleming (EM-43), Stephen Warren (EM-43), and Andy Wallo (EH-41). In addition, the project benefited from interactions with personnel working on the related tasks funded by EM-77, notably Michael Gresalfi (Oak Ridge National Laboratory [ORNL]), Kathy Yuracko (ORNL), Bob Lehrter (Fluor Daniel Fernald), and Jim Wells (Fluor Daniel Fernald). 


\section{NOTATION}

The following is a list of the acronyms, initialisms, and abbreviations (including units of measure) used in this document. Acronyms used only in tables or figures are defined in the respective tables or captions.

\section{ACRONYMS, INITIALISMS, AND ABBREVIATIONS}

$\begin{array}{ll}\text { ALARA } & \text { as low as reasonably achievable } \\ \text { ARAR } & \text { applicable or relevant and appropriate requirement } \\ \text { CERCLA } & \text { Comprehensive Environmental Response, Compensation, and Liability Act } \\ \text { CFR } & \text { Code of Federal Regulations } \\ \text { DEAR } & \text { U.S. Department of Energy Acquisition Regulation } \\ \text { DNFSB } & \text { Defense Nuclear Facilities Safety Board } \\ \text { DOE } & \text { U.S. Department of Energy } \\ \text { EPA } & \text { U.S. Environmental Protection Agency } \\ \text { FEMP } & \text { Fernald Environmental Management Project } \\ \text { FERMCO } & \text { Fernald Environmental Restoration Management Corp. } \\ \text { ISRI } & \text { Institute of Scrap Recycling Industries } \\ \text { IUD } & \text { intrauterine device } \\ \text { LBL } & \text { Lawrence Berkeley Laboratory } \\ \text { LLW } & \text { low-level waste } \\ \text { MDCR } & \text { maximum detectable count rate } \\ \text { MEI } & \text { maximally exposed individual } \\ \text { NLO } & \text { National Lead of Ohio } \\ \text { NPV/LCC } & \text { net present value of the life cycle cost } \\ \text { NRC } & \text { U.S. Nuclear Regulatory Commission } \\ \text { NTS } & \text { Nevada Test Site } \\ \text { OU3 } & \text { Operable Unit } 3 \\ \text { RESRAD } & \text { residual radioactive material guidelines (computer code) } \\ \text { ROD } & \text { Record of Decision } \\ \text { SCQ } & \text { Sitewide CERCLA Quality Assurance Project Plan } \\ & \end{array}$

\section{CHEMICALS}

$\begin{array}{llll}\mathrm{Al} & \text { aluminum } & \mathrm{NO}_{\mathrm{x}} & \text { nitrogen oxides } \\ \mathrm{As} & \text { arsenic } & \mathrm{O}_{2} & \text { oxygen } \\ \mathrm{C} & \text { carbon } & \mathrm{P} & \text { phosphorus } \\ \mathrm{Cd} & \text { cadmium } & \mathrm{Pb} & \text { lead } \\ 60 \mathrm{Co} & \text { cobalt } 60 & \mathrm{Si} & \text { silicon } \\ \mathrm{Cr} & \text { chromium } & \mathrm{SO}_{2} & \text { sulfur dioxide } \\ \mathrm{Cu} & \text { copper } & 99 \mathrm{Tc} & \text { technetium-99 } \\ \mathrm{Fe} & \text { iron } & 234 \mathrm{U} & \text { uranium-234 } \\ \mathrm{Mg} & \text { magnesium } & 235 \mathrm{U} & \text { uranium-235 } \\ \mathrm{Mn} & \text { manganese } & 238 \mathrm{U} & \text { uranium-238 } \\ \mathrm{Ni} & \text { nickel } & & \end{array}$




\section{UNITS OF MEASURE}

$\begin{array}{llll}{ }^{\circ} \mathrm{C} & \text { degree(s) Celsius } & \mathrm{lb} & \text { pound(s) } \\ \mathrm{cm} & \text { centimeter(s) } & \mathrm{m} & \text { meter(s) } \\ \mathrm{cm}^{2} & \text { square centimeter(s) } & \mathrm{mm} & \text { millimeter(s) } \\ \mathrm{cm}^{3} & \text { cubic centimeter(s) } & \mathrm{mrem} & \text { millirem } \\ \mathrm{d} & \text { day(s) } & \mathrm{oz} & \text { ounce(s) } \\ \mathrm{dpm} & \text { disintegration(s) per minute } & \mathrm{pCi} & \text { picocurie(s) } \\ \mathrm{ft}^{2} & \text { square foot (feet) } & \mathrm{ppb} & \text { part(s) per billion } \\ \mathrm{ft}^{3} & \text { cubic foot (feet) } & \mathrm{ppm} & \text { part(s) per million } \\ \mathrm{g} & \text { gram(s) } & \mathrm{s} & \text { second(s) } \\ \mathrm{h} & \text { hour(s) } & \mathrm{t} & \text { tonne(s) [metric ton(s)] } \\ \text { in. } & \text { inch(es) } & \text { ton } & \text { ton (short) } \\ \mathrm{J} & \text { joule(s) } & \mathrm{V} & \text { volt(s) } \\ \mathrm{kg} & \text { kilogram(s) } & \mathrm{yr} & \text { year(s) } \\ \mathrm{L} & \text { liter(s) } & & \end{array}$




\title{
AUTHORIZED LIMITS FOR FERNALD COPPER INGOTS
}

\author{
by \\ N. Frink, S. Kamboj, J. Hensley, and S-Y. Chen
}

\section{SUMMARY}

This development document contains data and analyses to support the approval of authorized limits for the unrestricted release of $59 \mathrm{t}$ of copper ingots containing residual radioactive material from the U.S. Department of Energy (DOE) Fernald Environmental Management Project (FEMP). The analyses presented in this document comply with the requirements of DOE Order 5400.5, "Radiation Protection of the Public and the Environment," as well as the requirements of the proposed promulgation of this order as 10 CFR Part 834. The document was developed following the step-by-step process described in the Draft Handbook for Controlling Release for Reuse or Recycle of Property Containing Residual Radioactive Material. ${ }^{1}$

Potential alternatives for disposition of the copper ingots were screened to identify appropriate alternatives for in-depth analysis. Alternatives initially considered included longterm storage, on-site and off-site disposal, restricted reuse, and unrestricted release for recycling. Two alternatives were selected for in-depth analysis: (1) unrestricted release for recycling in the secondary copper industry, and (2) off-site disposal as low-level waste. To support the development of authorized limits, the following analyses were completed: description of the copper ingots; definition of the proposed and alternative disposition methods; dose assessment; cost analysis; and ALARA analysis (to keep exposure "as low as reasonably achievable" [ALARA]).

To develop authorized limits for release, dose assessments for the "actual and likely" and the "worst plausible" release scenarios were conducted. The actual and likely release scenario involves recycle of the ingots at a secondary copper refinery and use of the recycled copper in electrical wiring and plumbing tube in residential applications. This scenario results in estimated doses to the maximally exposed individual (MEI) of less than $0.02 \mathrm{mrem} / \mathrm{yr}$ for a worker (slag worker in the copper refinery) and less than $0.0008 \mathrm{mrem} / \mathrm{yr}$ for a member of the general public (household member drinking tap water). The collective dose to the public from all exposures is estimated to be less than 0.1 person-rem. The actual and likely use scenario also turned out to be the worst plausible scenario, resulting in individual radiation exposures higher than those modeled for other less probable scenarios involving manufacture of the refined copper into intimate-use products.

The estimated doses to the MEI under the actual and likely use scenario are well below the 100-mrem annual dose limit specified in DOE Order 5400.5 or the proposed 10 CFR

\footnotetext{
1 U.S. Department of Energy, 1997, Draft Handbook for Controlling Release for Reuse or Recycle of Property Containing Residual Radioactive Material, Office of Environmental Management, Germantown, Md., March.
} 
Part 834. These estimated doses also satisfy ALARA objectives (maintaining radiation exposures as low as reasonably achievable), with doses less than a few millirem per year for the MEI and collective doses well below 10 person-rem. Cost estimates demonstrate that the alternative of unrestricted release for recycle is more cost-effective than off-site disposal, actually generating revenue for DOE. The ALARA analysis confirms that exposures to workers and the public are as low as reasonably achievable under the recycle alternative, with further reduction of the already low exposures impractical.

Implementation of the release alternative would result in the reutilization of a valuable resource, consistent with national priorities and DOE policy. Recycling supports the economically important domestic copper industry, which relies heavily on the recycle of scrap copper to maintain production competitive with foreign producers. In addition, recycling scrap copper reduces worker risk and environmental impacts associated with mining and beneficiating sufficient copper ore to produce an equivalent amount of refined copper.

Table S.1 summarizes the specific authorized limits requested for unrestricted release of the $59 \mathrm{t}$ of Fernald copper ingots. Upon approval of these limits, property management procedures will be implemented to dispose of the ingots (e.g., under an invitation for bid or negotiated sale). Prior to release of the ingots, sampling and monitoring will be conducted to verify that the material meets the authorized limits. Any required surface decontamination will be completed, and the ingots will be packaged and staged for transfer.

Precedent exists for release and recycling of volumetrically contaminated scrap copper from DOE operations. Lawrence Berkeley Laboratory (LBL) obtained approval for the release of scrap copper consisting of the activated electromagnet coil windings removed from the LBL 184-in. cyclotron. ${ }^{2}$ Release limits were approved for approximately $140 \mathrm{t}$ of copper containing ${ }^{60} \mathrm{Co}$ at levels less than $20 \mathrm{pCi} / \mathrm{g}$. The proposed FEMP release would result in exposures that would be comparable to the LBL release. Figure S.1 illustrates how exposures from release of the LBL and Fernald copper compare with a variety of existing release standards and dose limits.

TABLE S.1 Proposed Authorized

Limits for Release of Fernald Copper Ingots

\begin{tabular}{|c|c|}
\hline Parameter & Proposed Limit \\
\hline Uranium & $5 \mathrm{pCi} / \mathrm{g}(2 \mathrm{ppm})^{\mathrm{a}}$ \\
\hline${ }^{99} \mathrm{Tc}$ & $530 \mathrm{pCi} / \mathrm{g}(20 \mathrm{ppb})$ \\
\hline
\end{tabular}

a Section 3.4 of the main text provides the distribution of uranium isotopes.

2 U.S. Department of Energy, 1993, Environmental Assessment for the Recycling of Slightly Activated Copper Coil Windings from the 184-Inch Cyclotron at Lawrence Berkeley Laboratory, DOE/EA-0851, Berkeley, Calif., Oct. 


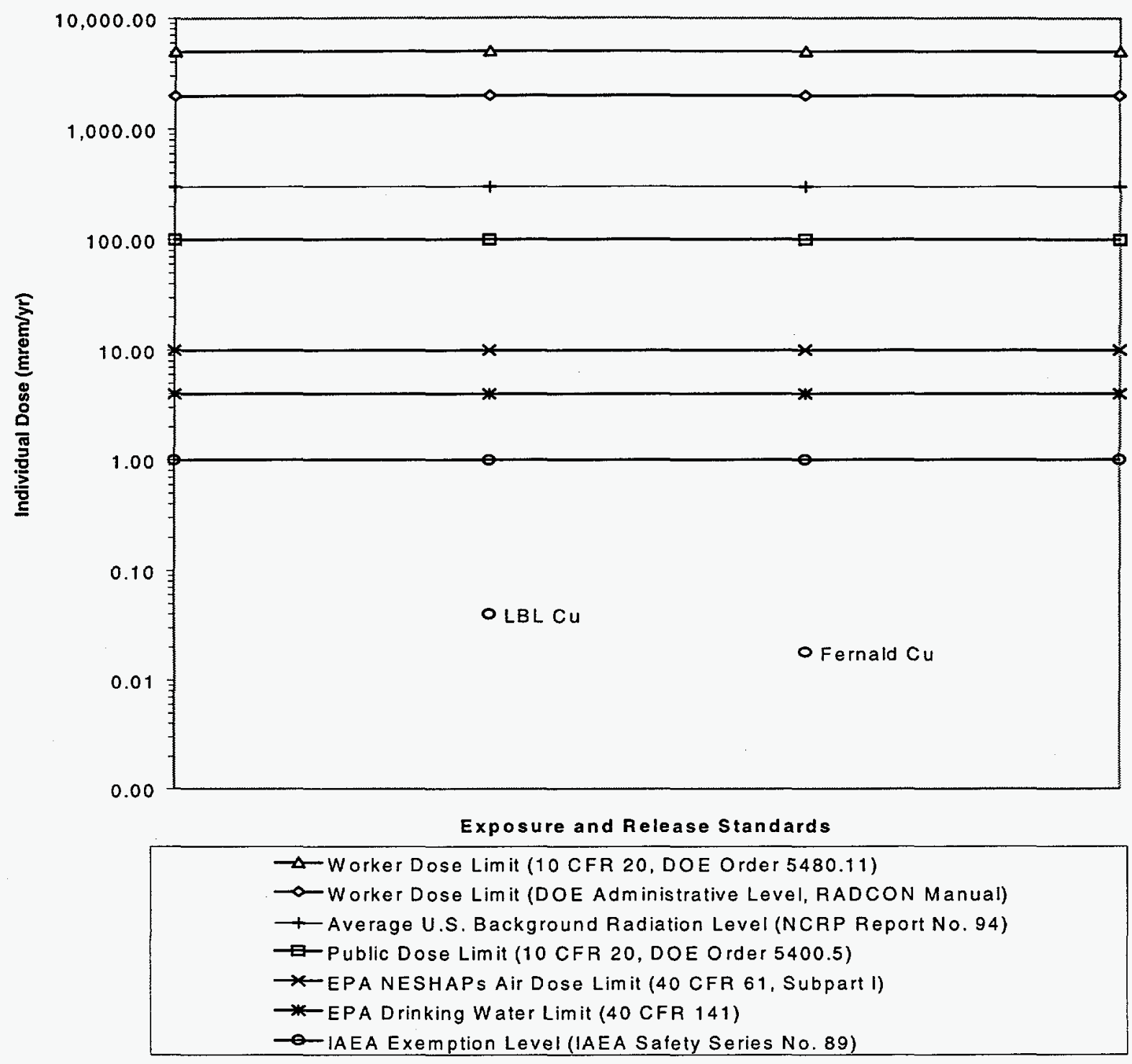

FIGURE S.1 Comparison of Dose with Existing Release Standards and Dose Limits (EPA = U.S. Environmental Protection Agency; IAEA = International Atomic Energy Agency; NCRP = National Commission for Radiological Protection and Measurements; and NESHAPs = National Emission Standards for Hazardous Air Pollutants) 
The Decision Methodology for Fernald Material Disposition Alternatives ${ }^{3}$ describes a methodology to help decision makers compare and select among competing alternatives for the disposition of materials from FEMP. The methodology requires that three "threshold criteria" be met in order for alternatives to undergo further consideration for implementation: (1) protectiveness of human health and the environment, (2) compliance with applicable or relevant and appropriate requirements (ARARs) and consistency with the Record of Decision (ROD), and (3) cost within 25\% of the lowest-cost alternative that meets the first two criteria. The analyses contained in this document may be used directly to assess these threshold criteria for competing disposition alternatives for the Fernald copper ingots.

Release under the proposed authorized limits is protective of human health and complies with ALARA principles. Implementation is consistent with the DOE commitment to balanced disposition approaches for materials generated during remediation of the Fernald site and complies with all ARARs. The proposed release of $59 \mathrm{t}$ of Fernald copper would generate revenue of about $\$ 56,000$ for DOE, compared with a cost of $\$ 42,550$ to dispose of the copper off-site as low-level waste.

3 U.S. Department of Energy, 1997, Decision Methodology for Fernald Material Disposition Alternatives, Fernald, Ohio, May 9. 


\section{INTRODUCTION}

This development document contains data and analyses to support the approval of authorized limits for the unrestricted release of $59 \mathrm{t}$ of copper ingots containing residual radioactive material for recycle and reuse from the U.S. Department of Energy (DOE) Fernald Environmental Management Project (FEMP). The analyses contained in this document comply with the requirements of DOE Order 5400.5, "Radiation Protection of the Public and the Environment" (DOE 1990), as well as the requirements of the proposed 10 CFR Part 834 (DOE 1993), which will codify and clarify DOE Order 5400.5 . The document was developed following the step-by-step process described in the Draft Handbook for Controlling Release for Reuse or Recycle of Property Containing Residual Radioactive Material (DOE 1997a).

The Fernald copper ingots were generated in 1980 in a process designed to recover DOE copper for recycle and reuse. Scrap copper wire originating from the DOE gaseous diffusion plants was shredded, separated from insulation and contaminants (fluff), and melted in an induction furnace. The majority of the radiological contamination was separated from the copper with the fluff. The copper was decontaminated further during the melting process when radionuclides partitioned into the slag phase from the melt. The resulting ingots contained very low levels of residual radioactive material (uranium at about $4.25 \mathrm{pCi} / \mathrm{g}$ ). The copper ingots, in storage for nearly 20 years, are considered part of the legacy of waste associated with Operable Unit 3 (OU3) of FEMP.

Section 2 of this document describes the regulatory requirements and policy objectives that drive selection of an alternative for disposition of the copper ingots. Regulatory requirements bound the domain of acceptable outcomes for decision making, and policy considerations provide a means for ranking and selecting among competing acceptable alternatives.

A description of the Fernald copper ingots, including their origin and their physical, chemical, and radiological characterization, is provided in Section 3. This information, in concert with the profile of the secondary copper industry contained in the Appendix, provides the basis for developing the unrestricted-release alternatives considered in the remaining sections of this document.

The preferred and alternative methods of disposition for the Fernald copper ingots are discussed in Section 4. Seven alternatives were subjected to a screening analysis: (1) continued storage; (2) on-site disposal; (3) off-site disposal at a licensed facility; (4) restricted reuse (within the DOE complex); (5) decontamination followed by restricted reuse; (6) unrestricted release; and (7) decontamination followed by unrestricted release. Alternatives were initially screened on the basis of technical viability, compliance with applicable or relevant and appropriate requirements (ARARs) and the Record of Decision (ROD), and cost. Only two alternatives passed the initial screening for in-depth analysis: (1) unrestricted release for recycling in the secondary copper industry, and (2) off-site disposal as low-level waste (LLW).

Dose assessments, cost estimates, and ALARA evaluations (to keep exposure "as low as reasonably achievable" [ALARA]) are provided in Sections 5 through 7. These interrelated analyses form the basis for development of authorized limits. Additional decision-making 
criteria, including schedule impacts, local economic impacts, institutional preferences, local social preference, and environmental impacts, are presented in Section 8. These criteria are assessed qualitatively, comparing the impacts associated with recycling the copper ingots in the secondary copper industry versus disposing of the ingots and replacing the copper with primary copper (copper derived from ore).

A discussion of required preparation prior to release for recycle under the preferred alternative is provided in Section 9. Preparation activities include surface decontamination, verification survey and analysis, packaging, and compilation of the required release documentation (i.e., appropriate records demonstrating compliance with approved authorized limits, applicable environmental regulations, property management procedures, acquisition regulations, and notifications to regulators and the receiving party). Section 10 describes in detail the survey and analysis methods proposed to demonstrate compliance with the authorized limits.

Stakeholder involvement played a key role in developing this application. Coordination meetings were held with state and federal regulators, and public meetings were held to ensure adequate stakeholder input into the process. A summary of the coordination efforts, the key stakeholder concerns identified, and the approaches implemented to resolve these concerns is presented in Section 11. 


\section{REGULATORY FRAMEWORK AND POLICY CONSIDERATIONS}

The decision about the disposition of the $59 \mathrm{t}$ of copper from Fernald is controlled by both regulatory requirements and policy objectives. Regulatory requirements define the threshold conditions under which material may be released on the basis of authorized limits. Policy considerations provide additional criteria for determining whether to proceed with release on the basis of authorized limits or whether to select a competing disposition alternative, such as disposal as LLW.

\subsection{REGULATORY FRAMEWORK}

The DOE Order 5400.5 contains provisions for unrestricted release of the copper ingots. Specifically, Chapter IV of the order describes the requirements for establishing authorized limits for the release of property containing residual radioactive material. The guidance is further augmented by an interim position issued from the DOE Office of Safety. Authorized limits may be approved on the basis of showing that radiation doses to workers and the public are acceptably low and that the activity meets ALARA principles (maintaining exposures "as low as reasonably achievable") and dose objectives. Under DOE Order 5400.5, an application for authorized limits describing dose assessment and ALARA analyses must be presented to the DOE Office of Safety for approval.

Currently, DOE is moving toward codification of its orders relating to nuclear safety. On March 25, 1993, DOE published a proposed rule in the Federal Register to codify DOE Order 5400.5 as $10 \mathrm{CFR}$ Part 834 and to clarify the requirements for implementation (DOE 1993). The DOE received and reviewed public comments on the proposed rule and is preparing for release of the final rule. The final rule will describe in further detail the requirements for establishment of authorized limits for release of residual radioactive material. In addition, the final rule will place authority for approval of authorized limits at the level of the DOE Field Office.

In March 1997, DOE published the Draft Handbook for Controlling Release for Reuse or Recycle of Property Containing Residual Radioactive Material (DOE 1997a). The handbook describes a step-by-step process designed to meet the requirements of current DOE Order 5400.5 and proposed 10 CFR Part 834 for release of nonreal property from DOE sites when the preferred use involves recycle or reuse. The handbook provides specific guidance on the approach for developing authorized release limits. It also provides an example annotated outline and samples of write-ups for an application for authorized limits.

The handbook indicates that an application for authorized limits must contain the following information:

- The nature of the nonreal property to which the proposed limits will apply and its potentially restricted or unrestricted use; 
- The potential collective dose to the exposed population and the dose to those individual members of the public most likely to receive the highest dose in the "actual and likely" use scenario and the "worst plausible" use scenario;

- The cost and impact of actions to reduce levels of residual radioactive material and the dose reduction resulting from these actions (ALARA analysis);

- Other factors that relate to the ALARA process and the approval decisions;

- The limits requested for residual radioactive contaminants, including any restrictions on use following release;

- The measurement protocols and evaluation techniques proposed to determine compliance with contamination limits; and

- The mechanism(s) by which DOE will reasonably ensure that any restrictions on use following release will be enforced.

Table 1 identifies those sections of this document where this required information is found.

\subsection{POLICY CONSIDERATIONS}

The release of copper for beneficial reuse is driven by national priorities and DOE policy for resource recovery, waste minimization, and pollution prevention. The Pollution Prevention Act of 1990 establishes a national policy that chemical pollution should be prevented or eliminated at the source, should be recycled when prevention is not feasible, and should be disposed only as a last resort. Executive Order 12856 mandates pollution prevention leadership within the federal government. The executive order requires that all federal agencies develop voluntary goals to reduce their total release of toxic chemicals to the environment by $50 \%$ by December 31, 1999. Further, Executive Order 12873 requires more efficient use of natural resources by agencies of the federal government. The order goes beyond requiring the use of recycled products and requires federal agencies to work to conserve disposal capacity through cost-effective waste-prevention and recycling activities.

The DOE embraces pollution prevention as its primary strategy to reduce the generation of all waste streams in order to minimize the impact of departmental operations on the environment, reduce operational costs, and improve energy efficiency and the safety of DOE operations. Preventing pollution will reduce the waste management burden while eliminating the potential for future liability and cleanup. This approach is captured in the DOE Waste Minimization/Pollution Prevention Crosscut Plan. The Defense Nuclear Facilities Safety Board (DNFSB) has underscored the need for waste-management and pollution-prevention initiatives relative to low-level radioactive waste management. On September 8, 1994, the DNFSB issued Recommendation 94-2, which concluded that the DOE LLW program required improvement. 
TABLE 1 Crosswalk among Development Document Sections, Handbook Guidance, and Fernald Decision Methodology

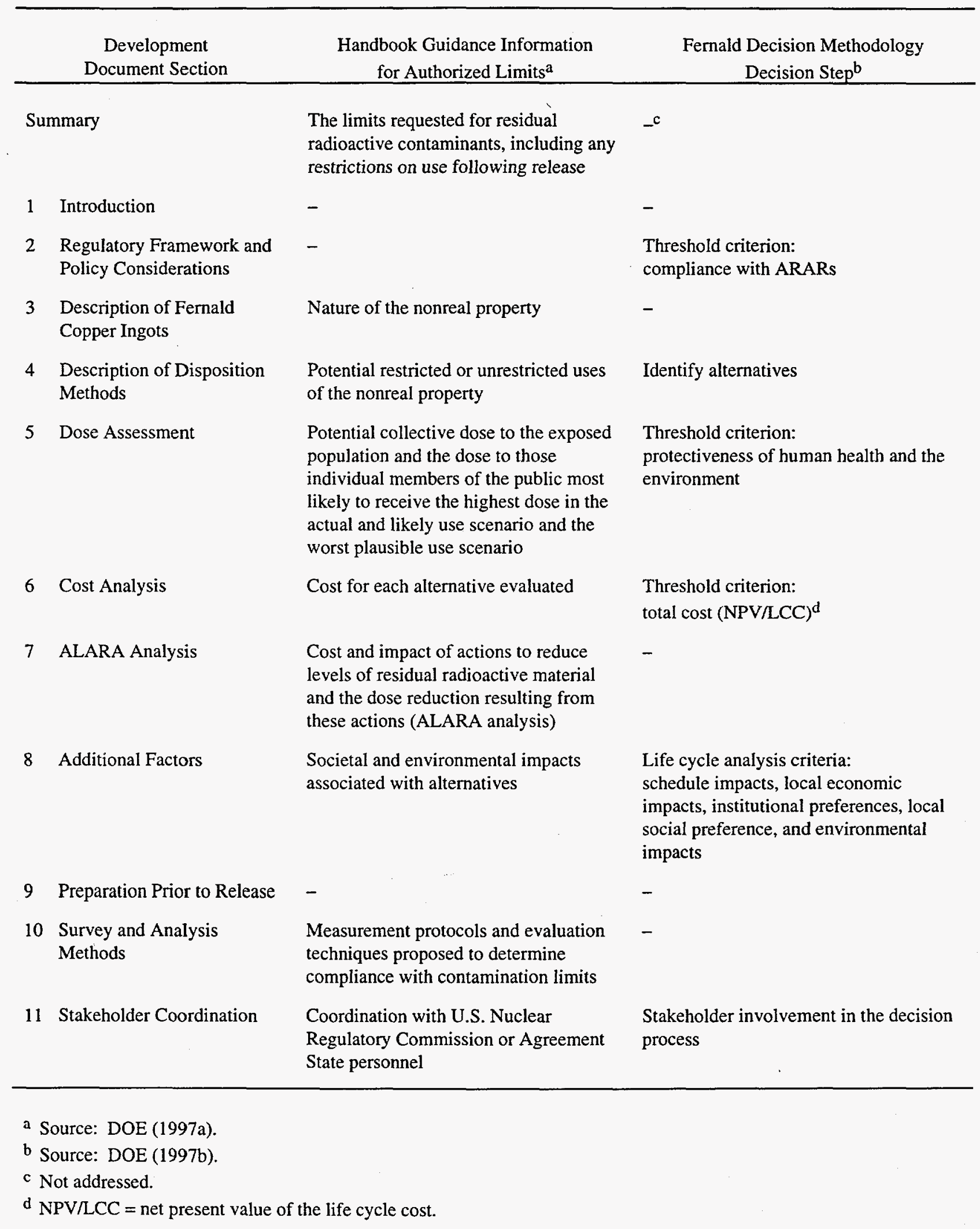


Specifically, the DNFSB recommended studies of enhanced methods that can be used to reduce the volume of waste to be disposed.

In September 1996, the DOE Office of Environmental Management issued its Policy on Recycling Radioactively Contaminated Carbon Steel (DOE 1996c). The policy is representative of the DOE commitment to initiatives for recycling to minimize the disposal of scrap metals as waste. This policy establishes a hierarchy for DOE action relative to radioactively contaminated scrap metal: release for unrestricted use if applicable release criteria are met; recycle for restricted use if unrestricted release is not economically feasible; and disposal as LLW if the material is not amenable for recycle into restricted-use products.

The DOE is committed to the safe, least-cost, earliest final cleanup of the Fernald site, within applicable DOE orders, regulations, and commitments and in a manner that addresses the concerns of stakeholders. The remediation effort at the site is being conducted under the authority of the Comprehensive Environmental Response, Compensation, and Liability Act (CERCLA). Under the Amended Consent Agreement, the Fernald site is divided into five operable units. Operable Unit 3 (OU3) encompasses the former production area, including its buildings and building contents. The ROD for OU3 describes the methodology to be used for completing the majority of the decontamination and decommissioning activities (DOE 1996b). Specifically, the ROD describes the approach for material disposition and includes a provision for implementing metal-recycling initiatives where feasible.

The DOE Fernald Site Office established an approach for comparing and selecting among competing proposals for the disposition of radioactive scrap metal in accordance with policy objectives. The approach, described in the Decision Methodology for Fernald Material Disposition Alternatives (DOE 1997b), divides the process into three phases. In the first phase (threshold phase), the alternatives are evaluated on the basis of the "threshold criteria" of protectiveness of human health and the environment, compliance with ARARs and consistency with the ROD, and the total cost (which is defined as the net present value of the life cycle cost or NPV/LCC). Alternatives that fail to meet the minimum standards in terms of protectiveness or compliance with ARARs and with the ROD or that are not within $25 \%$ of the lowest-cost alternative that does meet the protectiveness and ARARs/ROD criteria receive no further consideration under the methodology.

In the second phase (life cycle analysis phase), the alternatives that meet the threshold criteria are evaluated in terms of six performance measures, including total cost, schedule impacts, local economic impacts, institutional preferences, local social preference, and environmental impacts. In the third phase (decision phase), the alternatives are ranked by using multiattribute decision analysis, in which the results of the analysis phase are normalized to yield an aggregate total score for each alternative. The alternative with the highest score becomes the highest ranking alternative under the methodology. The decision methodology also provides for significant and meaningful stakeholder involvement in the process. Table 1 provides a crosswalk among the sections of this document, the handbook, and the Fernald decision methodology. 


\section{DESCRIPTION OF FERNALD COPPER INGOTS}

The origin of the scrap copper processed by DOE to produce the Fernald copper ingots and also the production processes and equipment utilized are well documented. In addition, the physical, chemical, and radiological characteristics of the ingots were evaluated in detail and documented during the production runs (NLO 1981).

\subsection{MATERIAL ORIGIN AND PRODUCTION PROCESS}

Copper windings were generated from the upgrade of large electrical motors from the DOE gaseous diffusion plants in the mid-1970s. Approximately 1,090 t of scrap copper was transported to the Feed Materials Production Center at Fernald, Ohio, for conversion into copper ingots for beneficial reuse. The scrap copper included insulation, some of which contained asbestos and was slightly surface-contaminated with uranium. The isotopic level of uranium ranged from depleted $(0.2 \% 235 \mathrm{U})$ to slightly enriched $(1.8 \% 235 \mathrm{U})$. The copper windings were approximately $1.3 \mathrm{~cm}$ wide by $0.32 \mathrm{~cm}$ thick $(1 / 2 \mathrm{in.} \times 1 / 8 \mathrm{in}$.).

In 1978, the management and operations contractor (National Lead of Ohio [NLO]) for the Feed Materials Production Center submitted a proposal, which DOE approved, to decontaminate and smelt the scrap copper into ingots. The demonstration run consisted of the following steps:

- Motor windings were size-reduced and cleaned to separate insulation and contaminants.

- The resulting copper granules were melted in a vacuum induction furnace.

- With ground glass added as a fluxing agent, the melt was carried out at about $1,350^{\circ} \mathrm{C}$.

- The melted copper was cast in graphite molds and allowed to cool to room temperature.

- The ingot was top-cropped, weighed, and sampled.

- The top crops were remelted in a subsequent charge.

The demonstration run resulted in the decontamination and processing of about $10 \%$ of the copper windings, with a mass of $109 \mathrm{t}$. For various reasons, including concern over asbestos exposures during processing and the absence of volumetric release standards for slightly contaminated materials, the project was terminated after the demonstration run. The scrap ingots have remained in storage at FEMP for nearly 20 years.

In 1995, the Fernald Environmental Restoration Management Corp. (FERMCO) awarded a contract to Manufacturing Sciences Corporation to demonstrate a process for decontaminating 
the remaining scrap copper windings for unrestricted release using surface release criteria. Currently, no plan exists for the disposition of the volumetrically contaminated scrap copper ingots.

\subsection{PHYSICAL CHARACTERISTICS}

The smelting process resulted in 498 product copper ingots. In 1981, about half of the ingots $(50 \mathrm{t})$ were released for restricted reuse to Nuclear Industries, Inc., for manufacture of components for use at the Hanford site. In the interim, no additional DOE uses for the copper have been identified. The physical characteristics of the remaining 270 ingots $(59 \mathrm{t})$ are summarized in Table 2 . The surface quality of the ingots is comparable to commercially produced ingots (NLO 1981).

\subsection{CHEMICAL CHARACTERISTICS}

The ingots have high contained copper content (all greater than $99.5 \% \mathrm{Cu}$ ). Table 3 summarizes the chemical attributes of the copper ingots. Copper content is generally specified as copper plus silver, but the numbers reported in Table 3 do not include silver (i.e., reported copper content may be slightly low). On the basis of the chemical attributes of the copper, the ingots are classified as No. 2 copper (ISRI 1997).

\subsection{RADIOLOGICAL CHARACTERISTICS}

Prior to smelting, the scrap copper was only slightly surface-contaminated with uranium; however, given the geometry of the scrap copper windings and the reliance on handheld survey instrumentation, obtaining a good estimate of the premelt source term was difficult. Much of the radiological contamination was removed along with the insulating materials during the decontamination phase of processing. The smelting operation provided a second decontamination step as the uranium was partitioned preferentially into the slag from the melt. The slag was

TABLE 2 Physical Attributes of Remaining Fernald Copper Ingots

\begin{tabular}{ll}
\hline \multicolumn{1}{c}{$\begin{array}{c}\text { Physical } \\
\text { Attribute }\end{array}$} & \multicolumn{1}{c}{ Value } \\
\hline & \\
Total mass & $59 \mathrm{t}(130,000 \mathrm{lb})$ \\
Total number & $\sim 270$ ingots \\
Average mass & $220 \mathrm{~kg}(484 \mathrm{lb})$ \\
Geometry & $\begin{array}{l}\text { Cylindrical castings; } 18-20 \mathrm{~cm} \\
\text { in diameter; } 75 \mathrm{~cm} \text { in height }\end{array}$ \\
\hline
\end{tabular}


TABLE 3 Chemical Attributes of Fernald Copper Ingots

\begin{tabular}{llc}
\hline & & \\
Chemical & Percent Less than $\ldots$ & $\begin{array}{c}\text { Single High } \\
\text { Value (ppm) }\end{array}$ \\
\hline & & \\
$\mathrm{Cu}$ & $1.2 \%<99.7 \%$ pure & $-^{\mathrm{a}}$ \\
$\mathrm{O}_{2}$ & $98.2 \%<100 \mathrm{ppm}$ & Not reported \\
$\mathrm{Si}$ & $95.6 \%<100 \mathrm{ppm}$ & 607 \\
$\mathrm{P}$ & $99.8 \%<20 \mathrm{ppm}$ & 23 \\
$\mathrm{Fe}$ & $96 \%<100 \mathrm{ppm}$ & 458 \\
$\mathrm{Ni}$ & $96.8 \%<10 \mathrm{ppm}$ & 46 \\
$\mathrm{Cr}$ & $99.2 \%<10 \mathrm{ppm}$ & 17 \\
$\mathrm{Mg}$ & $97.2 \%<10 \mathrm{ppm}$ & 34 \\
$\mathrm{Al}$ & $93.8 \%<10 \mathrm{ppm}$ & 38 \\
$\mathrm{C}$ & $99.6 \%<40 \mathrm{ppm}$ & 48 \\
$\mathrm{~Pb}$ & $92.7 \%<200 \mathrm{ppm}$ & 258 \\
\hline
\end{tabular}

a $99.54 \%$ pure (single low).

subsequently disposed of as low-level radioactive waste. The residual radioactive material remaining after the smelting operation is homogeneously distributed within the cast shape. As such, characterization of the source term in the ingots with laboratory analytical methods yields very accurate results.

All of the ingots were sampled and analyzed for radiological characterization (NLO 1981). The average uranium concentration was determined to be $1.6 \mathrm{ppm}$, with enrichments ranging from $0.2 \%$ to $1.8 \%{ }^{235} \mathrm{U}$. The ingots were also analyzed for ${ }^{99} \mathrm{Tc}$, a suspected contaminant from the gaseous diffusion plant process, but all reported values were below the instrument detection limit $(20 \mathrm{ppb})$. On the basis of profiles of radionuclide distributions from the gaseous diffusion plant sites, the ${ }^{99} \mathrm{Tc}$ concentrations would be expected to be on the order of $0.3 \mathrm{pCi} / \mathrm{g}$ (Chen et al. 1995). Table 4 summarizes the distribution of radionuclides in the copper ingots.

The uranium activity concentration in the ingots is about $4.25 \mathrm{pCi} / \mathrm{g}$. This value is within the range of background levels of uranium in soils in Ohio (1.5-4.4 pCi/g) (DOE 1996a). The total amount of uranium with the entire remaining $59 \mathrm{t}$ of ingots is about $353 \mathrm{~g}$ (about $3 / 4 \mathrm{lb}$ ).

The DOE Order 5400.5 incorporates by reference the Regulatory Guide 1.86 surface release limits for uranium at 5,000 disintegrations per minute (dpm) per $100 \mathrm{~cm}^{2}$ for fixed contamination and at $1,000 \mathrm{dpm} / 100 \mathrm{~cm}^{2}$ for removable contamination (AEC 1974). If all of the contamination could be removed from within a single ingot and evenly distributed on its surface, the surface activity would be $31 \mathrm{dpm} / 100 \mathrm{~cm}^{2}$. This value is $3.1 \%$ of the surface release limit for removable contamination and $0.62 \%$ of the surface release limit for fixed contamination. 
TABLE 4 Activity Concentration of Radionuclides in Fernald Copper Ingots

Radionuclide Activity (pCi/g)

\begin{tabular}{rr}
${ }^{238} \mathrm{U}$ & 1.95 \\
$235 \mathrm{U}$ & 0.3 \\
${ }^{234} \mathrm{U}$ & 2.0 \\
${ }^{99} \mathrm{Tc}$ & $<526^{\mathrm{a}}$ \\
\hline
\end{tabular}

a Less than $20 \mathrm{ppb}$. 


\section{DESCRIPTION OF DISPOSITION METHODS}

Definition of the preferred and alternative disposition methods for development of authorized limits is a three-step process. First, a range of initial alternatives must be evaluated to select the most appropriate alternatives for in-depth analysis. Second, the selected alternatives must be well defined to facilitate credible dose and cost estimates. Finally, on the basis of initial results from dose and cost estimates, the alternatives may need to be refined (optimized) to ensure that they represent the best possible balance between technical effectiveness and costeffectiveness.

\subsection{INITIAL SCREENING OF ALTERNATIVES}

An initial screening of alternatives was completed to select the most appropriate alternatives for side-by-side comparison. Seven alternatives were screened for further analysis: (1) continued storage; (2) on-site disposal; (3) off-site disposal at a licensed facility; (4) restricted reuse (within the DOE complex); (5) decontamination followed by restricted reuse; (6) unrestricted release; and (7) decontamination followed by unrestricted release.

Factors considered in screening alternatives included (1) technical viability, (2) compliance with ARARs and consistency with the ROD, and (3) estimated cost. Table 5 identifies the alternatives screened and gives a brief rationale for the selection or rejection of each. Each alternative is discussed in further detail in the following paragraphs.

\subsubsection{No Action}

The no-action alternative (continued storage) was ruled out as inconsistent with the ROD for OU3, which calls for disposing of stored "legacy waste" at an off-site facility, leveling facilities and buildings, and placing those facility components that cannot be reused or recycled into an on-site disposal cell. Legacy waste includes waste not generated from, or associated with, remediation activities.

\subsubsection{On-Site Disposal}

On-site disposal was screened out because the copper ingots are defined as legacy waste and thus are prohibited from disposal in the on-site cell under the ROD for OU3. Legacy waste from operations at Fernald is being (1) released for recycle if surface release criteria are met, (2) transferred to other government or private facilities for restricted reuse, or (3) disposed of at an approved disposal facility (e.g., the Nevada Test Site or Envirocare of Utah) if the material cannot be reused or recycled. 
TABLE 5 Screening of Disposition Alternatives

\begin{tabular}{|c|c|c|}
\hline Alternative & In/Out & Rationale \\
\hline \multicolumn{3}{|l|}{ No Action } \\
\hline Continue to store indefinitely & Out & $\begin{array}{l}\text { Inconsistent with OU3 ROD, which calls for } \\
\text { dismantlement of FEMP structures and disposition of } \\
\text { building contents }\end{array}$ \\
\hline \multicolumn{3}{|l|}{ Disposal } \\
\hline On-site disposal cell & Out & $\begin{array}{l}\text { Inconsistent with OU3 ROD because the ingots, } \\
\text { classified as legacy waste, are not approved for on- } \\
\text { site disposal }\end{array}$ \\
\hline Off-site disposal as LLW & In & $\begin{array}{l}\text { Meets waste acceptance criteria for off-site disposal; } \\
\text { satisfies constraints on disposition of OU3 materials }\end{array}$ \\
\hline \multicolumn{3}{|l|}{ Restricted Reuse } \\
\hline Restricted reuse & Out & $\begin{array}{l}\text { No current market for reuse products incorporating } \\
\text { copper; not cost-effective to manufacture in a } \\
\text { controlled facility }\end{array}$ \\
\hline $\begin{array}{l}\text { Decontamination followed by } \\
\text { restricted reuse }\end{array}$ & Out & $\begin{array}{l}\text { No current market for reuse products incorporating } \\
\text { copper; not cost-effective to manufacture in a } \\
\text { controlled facility }\end{array}$ \\
\hline \multicolumn{3}{|l|}{ Unrestricted Release } \\
\hline Unrestricted release & In & $\begin{array}{l}\text { Technically viable; meets ARARs; meets OU3 } \\
\text { constraints on disposition; cost-effective }\end{array}$ \\
\hline $\begin{array}{l}\text { Decontamination followed by } \\
\text { unrestricted release }\end{array}$ & Out & $\begin{array}{l}\text { Surface decontamination inapplicable; cost of melt } \\
\text { refining prohibitive; electrorefining not } \\
\text { demonstrated/no facility }\end{array}$ \\
\hline
\end{tabular}

\subsubsection{Restricted Reuse}

The restricted-reuse alternative was screened out on the basis of poor demand for products made from restricted-reuse copper. Other contaminated metals with less intrinsic value (e.g., carbon steel) and higher levels of acceptable radioactive contamination are available at sites closer to U.S. Nuclear Regulatory Commission (NRC) licensed metal melt facilities for fabrication into shield blocks. Copper has been identified as a component material for certain disposal containers designed for high-activity wastes, but no container design has been selected for manufacture on a production scale. Copper for inclusion in a reuse product such as a disposal container would require processing the copper in a controlled facility to produce required product shapes. The cost impacts of manufacturing in a controlled facility may make inclusion of reuse copper not cost-effective. Decontamination prior to reuse was screened out for similar reasons. 


\subsubsection{Decontamination Prior to Release}

Decontamination prior to unrestricted release was screened out for several reasons. Surface decontamination techniques would not be capable of addressing the volumetric contamination. Only a limited number of licensed facilities could conduct melt-refining decontamination, and no licensed facilities are currently capable of conducting electrorefining. No other mature technologies for decontaminating the copper ingots have been identified. Finally, because contamination levels in the copper ingots are sufficiently low, the cost of further decontamination likely would not yield commensurate benefit. The ALARA analysis contained in Section 7 of this document provides a detailed discussion of the costs and benefits associated with further decontamination prior to release.

\subsection{UNRESTRICTED RELEASE FOR RECYCLE}

Copper that meets approved authorized limits may be released to the secondary copper industry for refining, fabrication into end-use products, and subsequent public use of those products. To establish authorized limits, a dose assessment must be completed to demonstrate that doses to the public are as low as reasonably achievable (ALARA) below the primary dose limits. Primary dose limits are $100 \mathrm{mrem} / \mathrm{yr}$ for individuals from all sources at the DOE site. The goal is to maintain, through application of the ALARA process, low individual doses (e.g., a few millirem per year). Collective doses (the sum of the doses to all persons from exposures from a particular source) are used to compare costs and other factors when implementing the ALARA process.

The authorized limits are selected to ensure that doses to individuals using the property under "actual and likely" use scenarios would be well below the primary dose limits and should be on the order of a few millirem per year, or less, for continuous exposure. "Actual and likely" use scenarios are those that have a fairly high probability of occurring and represent the expected use of the property. As a general guide, these scenarios should include scenarios that are plausible, are unlikely to substantially underestimate the dose, and have a reasonable chance of occurring within at least the first 50 years.

The evaluation also must consider the "worst plausible" use of the property over the long term. The "worst plausible" use represents a scenario that is credible over the long term. The period of assessment may extend beyond several hundred years, and the probability of the scenario ever occurring must be included in the review. Allowable doses for release of the property calculated under this type of scenario may be a relatively large fraction of the general dose limit if the probability of the scenario occurring is relatively low.

To complete the required dose assessments, therefore, defining the "actual and likely" and the "worst plausible" cases is necessary. For release and recycling of copper, two main components exist for each case: (1) worker exposures during refining and manufacture of coppercontaining products, and (2) public exposures from end-use applications. The "actual and likely" and "worst plausible" cases for each of these components are discussed in the following paragraphs. 


\subsubsection{Secondary Copper and Product Manufacturing}

Copper products may originate from recycled copper (secondary copper industry) or be produced from copper derived from ore (primary copper industry). The Appendix contains an overview of the secondary copper industry, including information on copper materials in commerce and the process for recycling scrap copper.

Five basic steps are involved in scrap copper processing: (1) scrap preparation (grading, sorting, and sizing); (2) smelting (smelting and converting); (3) refining (fire refining and electrorefining); (4) production of semifabricated forms (casting, hot working, cold working, and annealing); and (5) manufacturing end-use products (cold forming, hot and cold forging, machining, joining, and electrodeposition). Depending on its classification, scrap copper will require processing by some or all of these steps.

The steps involved in processing the Fernald copper ingots within the secondary copper industry can be predicted with a relatively high level of confidence on the basis of the characteristics of the scrap being released. The Fernald copper likely would be sent to a secondary copper refinery for recovery. The Fernald copper would not need to be sent to a smelter facility (for smelting and converting) because of its high contained copper content; however, it also would not be sent directly to a mill or foundry because it still contains chemical contaminants at levels too high to allow its direct use.

Refinery operations include fire refining (or melting in an anode furnace), often followed by electrorefining. Nearly $60 \%$ of the copper coming from refineries has gone through both processes. The electrorefining step substantially increases the purity of the copper, making it amenable to use in electrical applications. Under the unrestricted release alternative, the copper is assumed to go through the fire-refining process but is not given the benefit of additional purification that would come from electrorefining.

Following refining, the copper is processed into intermediate (semifabricated) forms. Intermediate forms are transported to manufacturers and incorporated into end-use products. These products are then distributed for use in commerce.

\subsubsection{End-Use Applications}

The types of end-use products manufactured for public use may be predicted on the basis of statistical data on the distributions of copper to end-use products. Then, for modeling purposes, one or more representative products may be selected to model potential doses. Four general product types have been identified: wire-mill products, brass-mill products, foundry products, and other products. Table 6 identifies the product distribution scenarios modeled for end-use copper products. Products that dominate the probability distributions are considered "actual and likely" end-use applications. The "worst plausible" use scenario is considered to be that use scenario that is credible over the long term that yields the highest radiation exposures, notwithstanding the fact that the probability of distribution of copper to that end-use product is relatively low (i.e., less than $1 \%$ ). 
TABLE 6 Product Distribution Scenarios

\begin{tabular}{|c|c|c|c|c|}
\hline Product Type & Modeled Product & $\begin{array}{c}\text { Fernald } \mathrm{Cu} \\
\text { Consumed } \\
(\%) \\
\end{array}$ & $\begin{array}{c}\text { Units } \\
\text { Manufactured }\end{array}$ & $\begin{array}{c}\text { Probability } \\
\text { of Use } \\
(\%)\end{array}$ \\
\hline Wire-mill product & $\begin{array}{l}\text { Building wire } \\
(89 \mathrm{~kg})\end{array}$ & 60 & 400 homes & 15 \\
\hline Brass-mill product & $\begin{array}{l}\text { Plumbing tube } \\
(68 \mathrm{~kg})\end{array}$ & 35 & 300 homes & 8 \\
\hline Foundry product & $\begin{array}{l}\text { Plumbing hardware } \\
(11 \mathrm{~kg})\end{array}$ & 2 & 110 homes & 6 \\
\hline \multirow[t]{5}{*}{ Other products } & $\begin{array}{l}\text { Jewelry: bracelet } \\
(71 \mathrm{~g})\end{array}$ & 1 & 8,000 bracelets & $<1$ \\
\hline & $\begin{array}{l}\text { Copper frying pan } \\
(1.2 \mathrm{~kg})\end{array}$ & 1 & 500 pans & $<1$ \\
\hline & $\begin{array}{l}\text { Musical instrument } \\
(1 \mathrm{~kg})\end{array}$ & 0.2 & 100 trumpets & $<1$ \\
\hline & $\begin{array}{l}\text { Sterling flatware, } \\
\text { 24-piece set } \\
(1.1 \mathrm{~kg})\end{array}$ & 1 & 7,200 sets & $<1$ \\
\hline & $\begin{array}{l}\text { Copper T } 380 \text { IUD }^{a} \\
(0.2 \mathrm{~g} \text { each })\end{array}$ & 0.01 & 35,000 IUDs & $<1$ \\
\hline
\end{tabular}

a IUD = intrauterine device.

\subsubsection{Building Wire}

Building wire is selected as a representative end use for the wire products market. Building wire constitutes nearly one-third of the copper used in wire product applications (CDA 1996b). Residential use is selected as a credible representative use. Residential construction accounts for about two-thirds of all construction use. Typically 12- and 14-gauge insulated wire is run behind 1.25-cm (1/2-in.) drywall. Residential use gives the longest exposure times, with a four-person family spending 16 hours in the home on a daily basis. On average, about $89 \mathrm{~kg}$ (195 lb) of copper wire is used in a single-family residence. 


\subsubsection{Plumbing Tube}

Plumbing tube is selected as the representative end use for the brass-mill product segment. Copper plumbing tube accounts for $18 \%$ of the brass-mill products (CDA 1996b). The average single-family home contains about $68 \mathrm{~kg}(151 \mathrm{lb})$ of copper plumbing tube. Exposures are likely to come from the slow dissolution of copper into the water traveling in the tube. Sampling by the U.S. Environmental Protection Agency (EPA) for the development of Safe Drinking Water Act regulations showed $0.22 \mathrm{ppm}$ of copper in residential drinking water at the tap (EPA 1991). Ingestion of tap water may be estimated at $2 \mathrm{~L} / \mathrm{d}$ for a $70-\mathrm{kg}$ person.

\subsubsection{Plumbing Hardware}

Plumbing hardware is selected as a representative end use for the foundry product segment. Plumbing hardware is typically yellow brass. In the average single-family residence, about $11 \mathrm{~kg}(24 \mathrm{lb})$ of plumbing hardware is used, including items such as valves, fittings, and fixtures (CDA 1996a).

\subsubsection{Other End-Use Products}

The remaining end-use products modeled are representative of intimate end-use products. These end uses were selected as credible and particularly sensitive end-use applications. The representative end uses selected for modeling include copper frying pans, copper jewelry, musical instruments, sterling silver flatware, and a copper intrauterine device (IUD) (contraceptive device).

Frying Pan. A copper frying pan is representative of applications where copper is used in the food service industries for its good thermal conductive properties. Normally, copper is not in direct contact with food, but solid copper cookware may still be used in limited circumstances. A typical solid copper frying pan has a mass of about $1.2 \mathrm{~kg}(2.6 \mathrm{lb})$.

Jewelry. Copper jewelry is representative of copper products that may be maintained in close contact with the skin (e.g., representative of copper coins). A copper bracelet with a mass of $71 \mathrm{~g}(2.5 \mathrm{oz})$ is selected for modeling doses from copper jewelry.

Musical Instrument. A musical instrument is another representative copper product that may be maintained in close contact with the skin. A trumpet with a mass of $1 \mathrm{~kg}(2.2 \mathrm{lb})$ is selected for modeling doses from a musical instrument. 
Flatware. Sterling silver flatware (made of an alloy containing $92.5 \%$ silver and $7.5 \%$ copper) is a representative end use for copper alloys used in intimate contact. An eight-place table setting has a mass of about $1.1 \mathrm{~kg}(2.4 \mathrm{lb})$, with $82 \mathrm{~g}(2.9 \mathrm{oz})$ of contained copper.

Intrauterine Device. Finally, the copper IUD, a contraceptive device, falls into a class of its own. A standard copper IUD contains $0.2 \mathrm{~g}$ of copper on a T-shaped polyethylene support (Garbay et al. 1992). About 350,000 women in the United States use IUDs (1.4\% of women aged 15-44 years who are using reversible birth control). A copper IUD has a useful life of up to eight years, although it can be removed earlier. The percentage of women using IUDs varies in different countries, with the highest reported values coming from Scandinavian countries (20-40\% of the women using reversible birth control use IUDs) (Population Council 1997).

\subsection{DISPOSAL AT OFF-SITE LOW-LEVEL-WASTE FACILITY}

Disposal of the copper ingots at the Nevada Test Site (NTS) is the currently available offsite disposal option. The material meets the NTS waste acceptance criteria in its current condition and would require no processing or treatment before disposal. Prior to shipment, the material would need to be repackaged to meet package weight limitations and to minimize disposal volume.

Worker exposures in packaging and preparation for shipment are covered under the FEMP Radiation Protection Program. Likewise, all exposures at NTS are covered by the NTS Radiation Protection Program, and long-term exposures associated with the material in the disposal environment are addressed under the performance assessment for the disposal cell. Public and worker exposures during transportation are indirectly controlled by U.S. Department of Transportation limits on both package and shipment radiation. This control provides a basis for minimizing both individual and collective exposures during transportation. Because worker exposures are all controlled under existing radiation protection programs and because doses associated with transportation are negligible, a dose assessment for the off-site disposal option is not required by DOE Order 5400.5 or the proposed 10 CFR Part 834 . 


\section{DOSE ASSESSMENT}

The dose assessment is a specific type of risk assessment concerned with estimating radiation doses to persons exposed to radioactive materials under defined scenarios. Dose assessment is a prospective analysis, projecting probable outcomes for future events on the basis of information known or reasonably estimable about the scenario being assessed.

\subsection{DOSE ASSESSMENT METHODOLOGY}

The RESRAD-RECYCLE computer code, version 2.22 (Nabelssi et al. 1996), was used to conduct the dose assessment. The RESRAD-RECYCLE computer code is a pathway analysis tool developed by DOE and designed to calculate potential radiation doses resulting from recycling of radioactive scrap metal and the reuse of surface-contaminated material and equipment (Nabelssi et al. 1996).

For purposes of assessment, the recycling process has been divided into six steps, and representative exposure scenarios have been considered for each step. Scenarios are developed to model potential exposure associated with (1) the transport of radioactively contaminated copper from the place of origin to a secondary copper refinery, (2) refining of the copper and production of semifabricated forms, (3) transportation of the copper forms to fabrication plants, (4) product manufacture, (5) product distribution, and (6) the use of products by the public.

For each step in the process, one or more exposures may exist that must be modeled. Figure 1 illustrates these basic steps and identifies the specific exposures modeled for each step.

\subsection{INPUT PARAMETERS}

Required input parameters for the copper to be recycled include quantity, location, shape and form, chemistry, and the concentration of radioactive constituents. Table 7 summarizes the initial activity concentrations of radionuclides in the scrap copper to be released.

As discussed in Section 3.4, the ${ }^{99} \mathrm{Tc}$ concentrations may be much lower (e.g., on the order of $1 \mathrm{pCi} / \mathrm{g})$. Using the detection limit $(526 \mathrm{pCi} / \mathrm{g})$ as the actual value in the dose assessment is a conservative assumption.

The by-products of the refining process are generally of three types: (1) refined metal, (2) slag, and (3) dust. Radionuclides that are present in the contaminated copper will be distributed among these three by-products during melting operations. The distribution among these products depends on the chemical properties of the radionuclides, the metallurgical composition of the scrap, the slag-forming substances normally added to the melt (fluxes), the melting temperature and oxidation conditions, and the melting method. Table 8 presents the radionuclide and mass partitioning factors used in this analysis. 


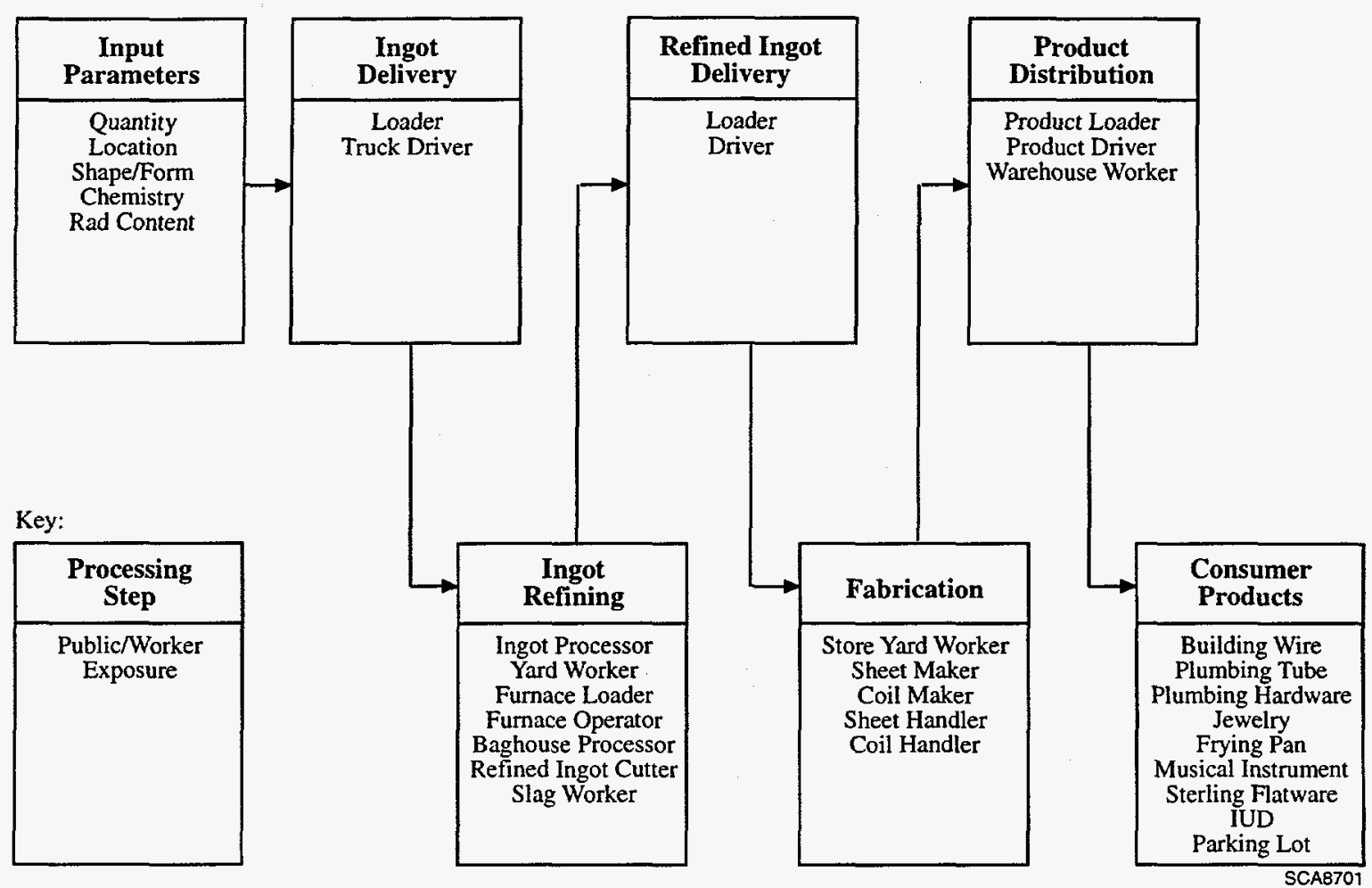

FIGURE 1 Pathways for Worker and Public Exposures during Copper Ingot Processing

TABLE 7 Initial Radionuclide

Concentrations in Fernald Copper

\begin{tabular}{cc} 
Radionuclide & Activity $(\mathrm{pCi} / \mathrm{g})$ \\
\hline & \\
$238 \mathrm{U}$ & 1.95 \\
$235 \mathrm{U}$ & 0.3 \\
$234 \mathrm{U}$ & 2.0 \\
${ }^{99} \mathrm{Tc}$ & $526^{\mathrm{a}}$ \\
\hline
\end{tabular}

a Equates to ${ }^{99} \mathrm{Tc}$ at $20 \mathrm{ppb}$. 
TABLE 8 Partitioning Factors for Fire Refining of Copper

\begin{tabular}{lccc}
\hline Constituent & $\begin{array}{c}\text { Refined Metal } \\
(\%)\end{array}$ & $\begin{array}{c}\text { Slag } \\
(\%)\end{array}$ & $\begin{array}{c}\text { Baghouse Dust } \\
(\%)\end{array}$ \\
\hline & & & \\
$\mathrm{Cu}$ & 97 & 1.1 & 1.7 \\
$235 \mathrm{U}$ & 100 & 100 & 0.1 \\
${ }^{234} \mathrm{U}$ & 100 & 100 & 0.1 \\
${ }^{238} \mathrm{U}$ & 100 & 100 & 0.1 \\
${ }_{99} \mathrm{Tc}$ & 10 & 100 & 0.1 \\
\hline
\end{tabular}

The radionuclide partitioning factors selected are very conservative because operational data are relatively scarce. The assumption that $100 \%$ of the activity goes both to the refined metal and to the slag phase artificially doubles the radioactive source term used in the dose calculations. This assumption is acceptable for the present analysis on the basis of the relatively low activity concentrations in the copper ingots, but this conservative assumption may be inappropriate in other circumstances.

Three exposure pathways are considered in the modeling: external, inhalation, and ingestion. Two general types of exposure scenarios are considered: (1) exposures to workers involved in the processing of recycled materials, and (2) exposures to individual members of the public using or otherwise being exposed to end-use products. The amount of radioactive metal recycled (throughput) affects the exposure duration of workers involved in each step of the recycling process. Table 9 details the exposure scenarios for workers and the parameters used in the calculations. The rest of the parameters are the RESRAD-RECYCLE default (Nabelssi et al. 1986).

Public exposures from end-use products are modeled for a selection of representative products on the basis of the distribution of copper to the various market segments. Exposure scenarios from end-use products include (1) building wire, (2) plumbing tube, (3) plumbing hardware, (4) frying pan, (5) jewelry (bracelet), (6) musical instrument, (7) sterling flatware, (8) copper IUD, and (9) parking lot (pavement) (slag). Table 10 details the key parameters and assumptions used for a throughput of $59 \mathrm{t}$ of copper to produce end-use products.

\subsection{DOSE ESTIMATES FOR RELEASE SCENARIOS}

Doses were calculated for workers and members of the public for release of the Fernald copper ingots. For each exposed group, individual doses, collective population doses, and cumulative population doses were calculated. Individual dose is the dose received by a single exposed individual in one year. Collective population dose is calculated by multiplying the individual committed effective dose equivalent by the number of people exposed, after adjusting the exposure duration to reflect the exposure duration used for the population dose assessment. The cumulative dose is the collective population dose delivered over the number of years of exposure to the population. 
TABLE 9 Worker Exposure Scenarios and Parameters

\begin{tabular}{|c|c|c|c|c|c|c|c|c|c|c|c|c|c|}
\hline Recycle Step & Scenario & $\begin{array}{c}\text { Source } \\
\text { Geometry } \\
\end{array}$ & $\begin{array}{c}\text { Mass } \\
(\mathrm{kg})\end{array}$ & $\begin{array}{l}\text { Density } \\
\left(\mathrm{g} / \mathrm{cm}^{3}\right)\end{array}$ & $\begin{array}{l}\text { Thickness } \\
(\mathrm{cm})\end{array}$ & $\begin{array}{c}\text { Radius } \\
(\mathrm{cm})\end{array}$ & $\begin{array}{c}\text { Distance } \\
(\mathrm{cm})\end{array}$ & $\begin{array}{c}\text { Time } \\
(\mathrm{h})\end{array}$ & $\begin{array}{c}\text { Mass } \\
\text { Partitioning } \\
\text { Factor } \\
\end{array}$ & $\begin{array}{c}\text { Radionuclide } \\
\text { Partitioning } \\
\text { Factor } \\
\end{array}$ & $\begin{array}{l}\text { Internal } \\
\text { Pathway } \\
\end{array}$ & $\begin{array}{c}\text { Dust } \\
\text { Loading } \\
\left(\mathrm{g} / \mathrm{cm}^{3}\right)\end{array}$ & $\begin{array}{c}\text { Number } \\
\text { of } \\
\text { Workers }\end{array}$ \\
\hline \multirow[t]{2}{*}{$\begin{array}{l}\text { Copper delivery } \\
\text { from Fernald }\end{array}$} & Loader & Half & 30,000 & 5.9 & 200 & 127 & 400 & 2 & None & None & $\begin{array}{l}\text { Inhalation and } \\
\text { ingestion }\end{array}$ & 0.001 & 2 \\
\hline & Truck driver & Half & 30,000 & 5.9 & 900 & 60 & 200 & 4 & None & None & None & 0 & 2 \\
\hline \multirow[t]{6}{*}{$\begin{array}{l}\text { Fire-refining } \\
\text { processes }\end{array}$} & Yard worker & Half & 60,000 & 8.9 & 140 & 175 & 1,000 & 80 & None & $\begin{array}{l}\text { Air for ingestion } \\
\text { and inhalation; } \\
\text { ingot for external }\end{array}$ & $\begin{array}{l}\text { Inhalation and } \\
\text { ingestion }\end{array}$ & 0.001 & 5 \\
\hline & Loader & Half & 60,000 & 8.9 & 200 & 146 & 400 & 4 & None & $\begin{array}{l}\text { Air for ingestion } \\
\text { and inhalation; } \\
\text { ingot for external }\end{array}$ & $\begin{array}{l}\text { Inhalation and } \\
\text { ingestion }\end{array}$ & 0.001 & 2 \\
\hline & Furnace operator & Full & 60,000 & 8.9 & 133 & 127 & 300 & 5 & None & $\begin{array}{l}\text { Air for ingestion } \\
\text { and inhalation; } \\
\text { ingot for external }\end{array}$ & $\begin{array}{l}\text { Inhalation and } \\
\text { ingestion }\end{array}$ & 0.003 & 2 \\
\hline & Baghouse processor & Full & 1,020 & 2.0 & 60 & 52 & 200 & 0.16 & Baghouse & Air & $\begin{array}{l}\text { Inhalation and } \\
\text { ingestion }\end{array}$ & 0.003 & 1 \\
\hline & Refined ingot caster & Full & 10,000 & 8.9 & 100 & 60 & 150 & 1 & Ingot & $\begin{array}{l}\text { Air for ingestion } \\
\text { and inhalation; } \\
\text { ingot for external }\end{array}$ & $\begin{array}{l}\text { Inhalation and } \\
\text { ingestion }\end{array}$ & 0.003 & 2 \\
\hline & Slag worker & Half & 660 & 2.7 & 15.6 & 100 & 150 & 10 & Slag & Slag & $\begin{array}{l}\text { Inhalation and } \\
\text { ingestion }\end{array}$ & 0.003 & 1 \\
\hline \multirow{2}{*}{$\begin{array}{l}\text { Refined ingot } \\
\text { delivery }\end{array}$} & Ingot loader & Half & 60,000 & 8.9 & 100 & 207 & 400 & 1 & Ingot & Ingot & None & 0 & 2 \\
\hline & Truck driver & Full & 30,000 & 8.9 & 200 & 73 & 200 & 4 & Ingot & Ingot & None & 0 & 2 \\
\hline \multirow{5}{*}{$\begin{array}{l}\text { Product } \\
\text { manufacture }\end{array}$} & Yard worker & Half & 60,000 & 8.9 & 100 & 207 & 1,000 & 40 & Ingot & Ingot & None & 0 & 5 \\
\hline & Sheet maker & Half & 60 & 8.9 & 0.2 & 147 & 100 & 1 & Ingot & Ingot & $\begin{array}{l}\text { Inhalation and } \\
\text { ingestion }\end{array}$ & 0.001 & 10 \\
\hline & Coil maker & Full & 15,000 & 8.9 & 122 & 66 & 150 & 0.5 & Ingot & Ingot & $\begin{array}{l}\text { Inhalation and } \\
\text { ingestion }\end{array}$ & 0.001 & 1 \\
\hline & Sheet handler & Half & 60 & 8.9 & 0.2 & 14 & 100 & 1 & Ingot & Ingot & None & 0 & 10 \\
\hline & Coil handler & Full & 15,000 & 8.9 & 122 & 66 & 150 & 40 & Ingot & Ingot & None & 0 & 5 \\
\hline \multirow{3}{*}{$\begin{array}{l}\text { Product } \\
\text { distribution }\end{array}$} & Product loader & Half & 60,000 & 8.9 & 100 & 207 & 400 & 20 & Ingot & Ingot & None & 0 & 2 \\
\hline & Truck driver & Full & 30,000 & 8.9 & 200 & 73 & 200 & 8 & Ingot & Ingot & None & 0 & 2 \\
\hline & Warehouse worker & Half & 300 & 8.9 & 1.2 & 134 & 600 & 2,000 & Ingot & Ingot & None & 0 & 2 \\
\hline
\end{tabular}




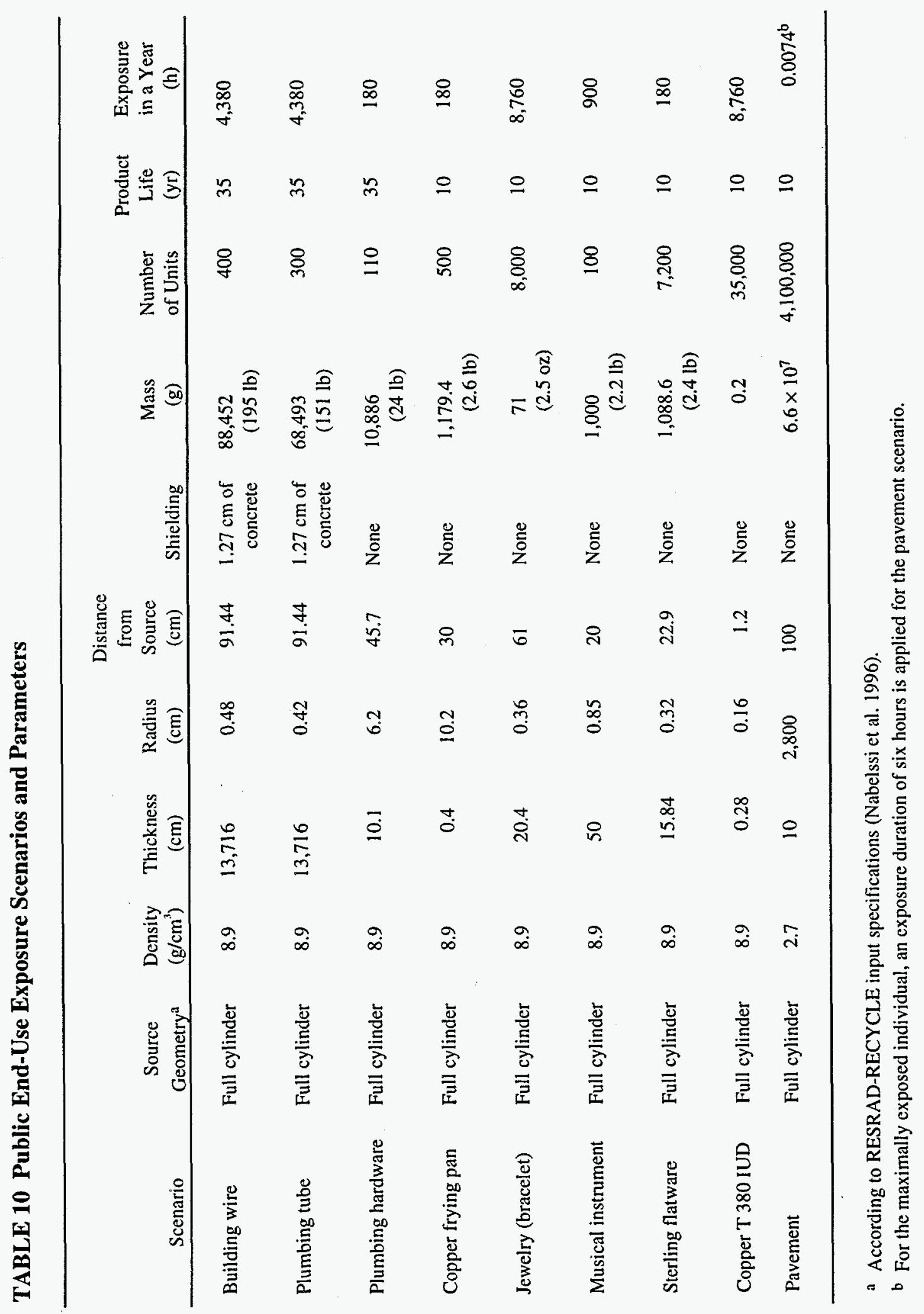


Table 11 specifies the calculated doses for worker exposures. Because the worker exposures all occur in less than one year, the collective dose and the cumulative dose are the same. The maximally exposed individual (MEI) in the worker exposure scenarios was the slag worker, receiving $0.02 \mathrm{mrem} / \mathrm{yr}$. Exposure of the slag worker is driven primarily by the inhalation of dust during slag-handling operations.

Table 12 summarizes the calculated doses for public exposures in end-use scenarios. Cumulative doses for end-use scenarios are calculated as the collective population dose delivered over the useful life of the end-use product. The MEI in the end-use scenario was the household member drinking tap water delivered in copper plumbing tube. The MEI receives less than $0.0008 \mathrm{mrem} / \mathrm{yr}$, and the exposure is primarily through the ingestion pathway. Individuals exposed to several other end-use products (frying pan, IUD, and pavement) had exposures within a factor of 10 below that calculated for the MEI.

The actual and likely scenario (refining of the copper ingots and subsequent manufacture into electrical wire and plumbing tube for residential applications) turned out to also be the worst plausible scenario. With MEI exposures well below the ALARA objective of a few millirem per year for both the actual and likely and the worst plausible use scenarios, authorized limits may be established to allow release of the Fernald copper ingots with no significant radiation exposure.

TABLE 11 Individual and Collective Doses in Worker Scenarios for Processing Fernald Copper Ingots

\begin{tabular}{llc}
\hline \multicolumn{1}{c}{ Scenario } & $\begin{array}{c}\text { Individual Dose } \\
\text { (mrem /yr) }\end{array}$ & $\begin{array}{c}\text { Collective Dose } \\
\text { (person-rem) }\end{array}$ \\
\hline Ingot loader & $1.31 \times 10^{-3}$ & $2.63 \times 10^{-6}$ \\
Ingot truck driver & $2.59 \times 10^{-6}$ & $5.17 \times 10^{-9}$ \\
Refinery yard worker & $7.06 \times 10^{-5}$ & $3.53 \times 10^{-7}$ \\
Refinery loader & $6.38 \times 10^{-6}$ & $1.28 \times 10^{-8}$ \\
Furnace operator & $2.20 \times 10^{-5}$ & $4.40 \times 10^{-8}$ \\
Baghouse processor & $1.83 \times 10^{-5}$ & $1.83 \times 10^{-8}$ \\
Refined ingot caster & $4.17 \times 10^{-6}$ & $8.34 \times 10^{-9}$ \\
Slag worker & $1.77 \times 10^{-2}$ & $1.77 \times 10^{-5}$ \\
Refined ingot loader & $1.75 \times 10^{-6}$ & $3.49 \times 10^{-9}$ \\
Refined ingot truck driver & $7.56 \times 10^{-6}$ & $1.51 \times 10^{-8}$ \\
Storage yard worker & $1.26 \times 10^{-5}$ & $6.31 \times 10^{-8}$ \\
Sheet maker & $6.69 \times 10^{-4}$ & $6.69 \times 10^{-6}$ \\
Coil maker & $3.35 \times 10^{-4}$ & $3.35 \times 10^{-7}$ \\
Sheet handler & $1.06 \times 10^{-6}$ & $1.06 \times 10^{-8}$ \\
Coil handler & $1.05 \times 10^{-4}$ & $5.27 \times 10^{-7}$ \\
Product loader & $3.49 \times 10^{-5}$ & $6.98 \times 10^{-8}$ \\
Product truck driver & $1.51 \times 10^{-5}$ & $3.02 \times 10^{-8}$ \\
Warehouse worker & $3.50 \times 10^{-4}$ & $7.01 \times 10^{-7}$ \\
\hline
\end{tabular}


TABLE 12 Individual, Collective, and Cumulative Doses for End-Use Product Scenarios for Fernald Copper Ingots

\begin{tabular}{lccc}
\hline \multicolumn{1}{c}{ Scenario } & $\begin{array}{c}\text { Individual Dose } \\
\text { (mrem/yr) }\end{array}$ & $\begin{array}{c}\text { Collective Dose } \\
\text { (person-rem) }\end{array}$ & $\begin{array}{c}\text { Cumulative Dose } \\
\text { (person-rem) }\end{array}$ \\
\hline Building wire & $1.58 \times 10^{-6}$ & $2.53 \times 10^{-6}$ & $8.84 \times 10^{-5}$ \\
Plumbing tube & $7.34 \times 10^{-4}$ & $8.81 \times 10^{-4}$ & $3.08 \times 10^{-2}$ \\
Plumbing hardware & $4.79 \times 10^{-5}$ & $2.11 \times 10^{-5}$ & $7.37 \times 10^{-4}$ \\
Frying pan & $5.49 \times 10^{-4}$ & $1.10 \times 10^{-3}$ & $1.10 \times 10^{-2}$ \\
Jewelry (bracelet) & $4.55 \times 10^{-6}$ & $3.64 \times 10^{-5}$ & $3.63 \times 10^{-4}$ \\
Musical instrument & $2.15 \times 10^{-5}$ & $2.15 \times 10^{-6}$ & $2.15 \times 10^{-5}$ \\
Sterling flatware & $4.75 \times 10^{-7}$ & $8.20 \times 10^{-5}$ & $8.20 \times 10^{-4}$ \\
Copper T 380 IUD & $1.23 \times 10^{-4}$ & $4.29 \times 10^{-3}$ & $4.29 \times 10^{-2}$ \\
Pavement & $3.10 \times 10^{-4}$ & $1.57 \times 10^{-3}$ & $1.57 \times 10^{-2}$ \\
\hline
\end{tabular}




\section{COST ANALYSIS}

A cost analysis of the competing disposition alternatives is required for several reasons. First, under the handbook guidance for developing authorized limits, cost is a key factor in optimizing alternatives to ensure that radiation exposures meet ALARA constraints. Second, the cost and schedule impacts of competing alternatives are key performance measures that must be considered in selecting among alternatives under the Fernald decision methodology. Generally, the net present value, the total undiscounted cost, and the potential schedule impacts are performance measures that are considered.

The cost analysis for the two competing alternatives is fairly simple because the copper ingots require little preparation prior to release to the disposition outlets. Table 13 provides the basis of the estimate for the two alternatives that passed the screening level, with monetary values assigned to the activities involved with each of the alternatives (all values in 1997 dollars).

TABLE 13 Basis of Estimate for Disposition Alternative Costs ${ }^{\mathbf{a}}$

\begin{tabular}{|c|c|c|}
\hline Element & Off-Site Disposal & Recycle \\
\hline Storage prior to release & $\begin{array}{l}\text { 1-yr storage; } \\
19 \text { containers; } \\
\text { \$0.08/container/d }\end{array}$ & No storage beyond FY1997 \\
\hline Storage cost & $\$ 500$ & $\$ 0$ \\
\hline Preparation for disposition & None & $\begin{array}{l}\text { Verification sampling and analysis; } \\
\text { monitoring, decontamination, and } \\
\text { repackaging }\end{array}$ \\
\hline Preparation cost & $\$ 0$ & $\$ 22,000$ \\
\hline Transportation to disposition outlet & $\begin{array}{l}3.25 \text { shipments to NTS; } \\
40,000 \mathrm{lb} / \text { shipment; } \\
\$ 3,000 / \text { shipment (rad) }\end{array}$ & Scrap price $\mathrm{FOB}^{\mathrm{b}}$ Fernald \\
\hline Transportation cost & $\$ 9,750$ & $\$ 0$ \\
\hline Disposition & $\begin{array}{l}1,900-\mathrm{ft}^{3} \text { disposal volume; } \\
\$ 17 / \mathrm{ft}^{3}\end{array}$ & $\begin{array}{l}130,000 \mathrm{lb} \text { of No. } 2 \text { scrap } \mathrm{Cu} \\
\$ 1,090 / \mathrm{t}(\$ 0.60 / \mathrm{lb})\end{array}$ \\
\hline Disposition cost & $\$ 32,300$ & $(\$ 78,000)^{\mathrm{c}}$ \\
\hline Total cost & $\$ 42,550$ & $(\$ 56,000)^{\mathrm{c}}$ \\
\hline
\end{tabular}
a All values in 1997 dollars.
b $\mathrm{FOB}=$ free on board (picked up by scrap dealer at Fernald).
c Numbers within parentheses indicate cost savings or revenue generated. 


\subsection{OFF-SITE DISPOSAL}

For off-site disposal, the following cost assumptions were made:

- No funding for disposal in FY 1997; funding available in FY 1998;

- Copper ingots not repackaged prior to disposal;

- No cost for preparation of waste certification paperwork;

- No additional waste characterization required;

- Disposal rate at NTS is $\$ 17 / \mathrm{ft}^{3}$; and

- Shipment to NTS is a radioactive waste shipment.

\subsection{RECYCLE}

For recycle, the following cost assumptions were made:

- Funding for ingot preparation available in FY 1997;

- Representative samples (seven) taken from ingots to verify prior sampling results;

- $100 \%$ of ingots require surface decontamination;

- $100 \%$ of ingots surveyed as they are repackaged;

- Repackaged ingots staged outside the controlled area for pickup by a broker; and

- Copper sold FOB (free on board) Fernald, Ohio, at $\$ 1,200 /$ ton $(\$ 0.60 / 1 b)$.

The standard criterion for deciding whether a government program can be justified on economic principles is net present value. Net present value is the discounted monetized value of expected net benefits (i.e., benefits minus costs). Net present value is computed by assigning monetary values to benefits and costs, discounting future benefits and costs by using an appropriate discount rate, and subtracting the sum total of discounted costs from the sum total of discounted benefits.

The calculated net present value is a $\$ 42,550$ cost for off-site disposal and a $\$ 56,000$ cost savings for unrestricted release. The net present value for unrestricted release exceeds off-site disposal by $\$ 98,550$. The net present values of off-site disposal and unrestricted release are presented graphically in Figure 2. 


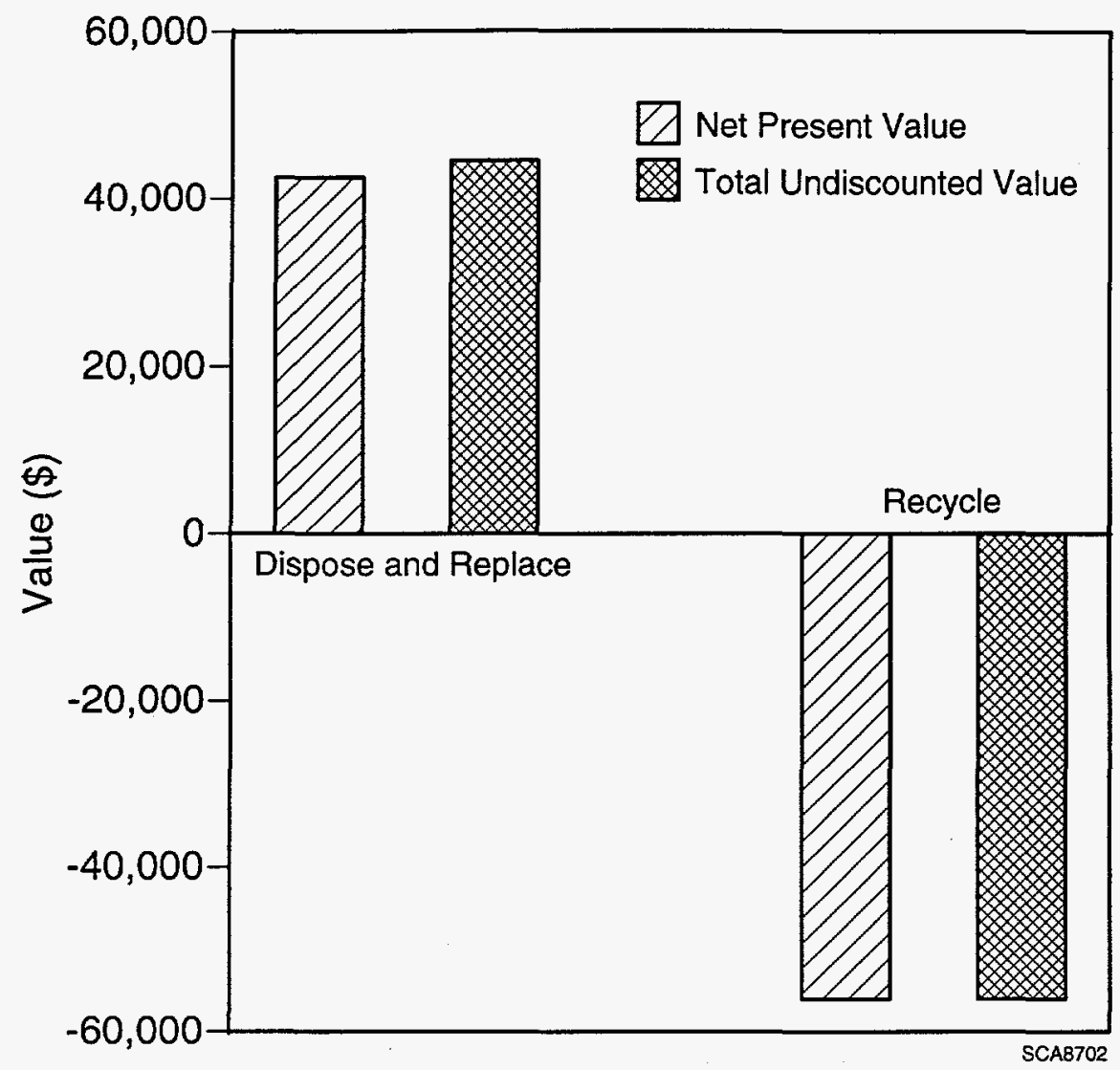

FIGURE 2 Cost for Fernald Ingot Disposition Alternatives 


\section{ALARA ANALYSIS}

Both DOE Order 5400.5 and the proposed 10 CFR Part 834 require that the selected alternative satisfy ALARA principles, maintaining exposure as low as reasonably achievable. Because the contamination in the copper ingots is volumetric (i.e., dispersed uniformly through the copper), options are limited for further decontamination prior to release to the general public. Melt refining is the only mature technology with a potential for reducing radionuclide concentrations in volumetrically contaminated copper. Electrorefining is a possible competing alternative, but currently no DOE or NRC licensed facilities have electrorefining capabilities. The melt-refining option would require that the copper be smelted in a radiologically controlled facility (i.e., a DOE facility or an NRC licensed facility) to partition the uranium preferentially into the slag phase. Under favorable conditions, with the addition of appropriate fluxing agents, up to $99 \%$ of the contaminants might be partitioned into the slag phase. This partitioning would result in a reduction in collective dose by a factor of 100 , reducing the collective exposure by about 0.1 person-rem.

Scientific Ecology Group melted FEMP scrap ferrous metal in a radiologically controlled environment at a cost of $\$ 2.42 / \mathrm{kg}(\$ 1.10 / \mathrm{b})$. The process generated a substantial quantity of slag, which was returned to FEMP for disposal as LLW. The DOE bore the cost of slag disposal above and beyond the $\$ 2.42 / \mathrm{kg}$ cost of melting. Melt refining generally requires more process control than does merely melting for volume reduction. A fully burdened cost of $\$ 2.50 / \mathrm{kg}$ provides a reasonable estimate of the cost to melt-refine the Fernald copper ingots to reduce radioactive contaminant levels. This estimate results in a cost of about $\$ 150,000$ to melt-refine $59 \mathrm{t}$, or $\$ 1.5$ million/person-rem. On the basis of this person-rem reduction cost and the already low projected collective exposures, the proposed alternative meets ALARA objectives without further modifications. 


\section{ADDITIONAL FACTORS}

Both the handbook guidance and the Fernald decision methodology take into account additional factors in weighing competing disposition alternatives. These factors are considered in addition to the primary decision-making criteria of protectiveness of human health and the environment, compliance with ARARs and consistency with the ROD, and cost. Factors identified in the Fernald decision methodology include schedule impacts, local economic impacts, institutional preferences, local social preference, and environmental impacts. In the decision phase of the Fernald decision methodology, values are assigned to each of these factors to provide a means for comparative ranking of the disposition alternatives. This ranking allows for construction of a decision summary matrix that may be used as a tool for selecting among competing alternatives that passed the screening or threshold phase of the analysis.

Additional factors are discussed below; Table 14 presents a tentatively completed decision summary matrix. Values that reflect institutional preferences must be verified by the institutional stakeholders (e.g., DOE and EPA). Local social preference values must be assigned on the basis of input received from public stakeholders through workshops, meetings, and other correspondence (no attempt has been made to presage public sentiment).

\subsection{SCHEDULE IMPACTS}

Schedule impacts can be an important performance measure for comparing disposition alternatives. Activities that are critically tied to other scheduled activities will be given significant consideration in comparing alternatives. Additionally, alternatives that expedite final site cleanup will generally be given preference. In the case of copper disposition, schedule impacts do not influence decision making. The impact of the disposition of 19 white metal boxes of material from storage over a two-year period is not expected to register as a schedule impact.

\subsection{LOCAL ECONOMIC IMPACTS}

Disposition of the Fernald copper ingots will not impact the local economy for a number of reasons. First, the amount of material for disposition is relatively small compared with the total quantity of scrap metal to be dispositioned from the site (e.g., compared with 14,000 tons of structural steel projected to come from building dismantlement). Second, the copper ingots require very little preparation for disposition under any alternative.

A constructed scale for evaluating impacts on local employment has been developed, under which each alternative is given a "score" of $1,2,3,4$, or 5 on the basis of the following definitions:

- A score of 1 means that the alternative would result in the loss of 25 or more person-years of employment; 
TABLE 14 Decision Summary Matrix

\begin{tabular}{lcc}
\hline & $\begin{array}{c}\text { Unrestricted Recycle } \\
\text { in Secondary } \\
\text { Copper Industry }\end{array}$ & $\begin{array}{c}\text { Dispose as LLW, } \\
\text { and Replace Copper } \\
\text { from Primary Ore }\end{array}$ \\
\hline $\begin{array}{l}\text { Cost } \\
\text { NPV/LCC } \\
\text { Unit cost }\end{array}$ & $\begin{array}{l}(\$ 56,000) \\
(\$ 30 / \mathrm{bcf})\end{array}$ & $\begin{array}{c}\$ 42,550 \\
\$ 22 / \mathrm{bcf}\end{array}$ \\
Schedule impacts & $1 \mathrm{yr}$ & $2 \mathrm{yr}$ \\
Local economic impacts & 3 & 3 \\
Institutional preferences & 5 & 2 \\
Local social preference & 5 & 3 \\
Environmental impacts & 5 & \\
\hline a Parentheses indicate negative cost (cost savings). & \\
b Per bank cubic foot (bcf) of scrap metal as prepared for disposition.
\end{tabular}

- A score of 2 means that the alternative would result in the loss of between 5 and 25 person-years of employment;

- A score of 3 means that the alternative would result in the gain or loss of less than 5 person-years of employment;

- A score of 4 means that the alternative would result in the gain of between 5 and 25 person-years of employment; and

- A score of 5 means that the alternative would result in the gain of 25 or more person-years of employment.

All alternatives considered for disposition of the Fernald copper ingots would result in a gain or loss of less than 5 person-years of local employment and would be assigned a " 3 " under the constructed scale described.

\subsection{INSTITUTIONAL PREFERENCES}

Institutional preferences address how well each alternative adheres to applicable governmental policies, such as resource conservation mandates, privatization considerations, preferences for reuse or recycle over disposal, and obligations to use final (rather than interim) 
solutions for site remediation. Institutional preferences address the views of DOE, EPA, and other federal, state, and local institutions and regulatory agencies.

A constructed scale has been developed for institutional preferences, under which each alternative is given a "score" of $1,2,3,4$, or 5 on the basis of the following definitions:

- A score of 1 means that the alternative uses interim (rather than final) solutions, does not include reuse or recycle, and lacks private participation;

- A score of 2 means that the alternative uses final solutions but does not include reuse or recycle and lacks private participation;

- A score of 3 means that the alternative uses final solutions and includes either (a) reuse or recycle or (b) private participation (but not both);

- A score of 4 means that the alternative uses final solutions and includes recycle or reuse but lacks private participation; and

- A score of 5 means that the alternative uses final solutions, includes recycle or reuse, and includes private participation.

The unrestricted-release alternative would score a "5": it provides a final solution, is a recycle alternative, and uses the commercial copper industry to accomplish the recycling. The off-site disposal alternative would receive a score of "2": it does provide a final solution but does not involve recycling or privatization initiatives.

\subsection{LOCAL SOCIAL PREFERENCE}

Local social preference is a measure of the degree to which competing disposition alternatives meet local stakeholder desires for FEMP remediation. This assessment is subjective on the part of the stakeholder, based on his or her individual, personal understanding of the alternatives, data, and other information pertinent to evaluating the issue. Public participation will be solicited for alternatives that pass the threshold screening criteria. Individual members of the public will be asked to indicate their preference by assigning a score of $1,2,3,4$, or 5 to each alternative on the basis of the following definitions:

- A score of 1 means that the alternative fails to meet local public stakeholder desires for FEMP remediation in many areas;

- A score of 2 means that the alternative fails to meet local public stakeholder desires for FEMP remediation in some (but not many) areas;

- A score of 3 means that the alternative fails to meet local public stakeholder desires for FEMP remediation in very few areas; 
- A score of 4 means that the alternative meets local public stakeholder desires for FEMP remediation in all areas; and

- A score of 5 means that the alternative meets local public stakeholder desires for FEMP remediation in all areas and exceeds stakeholder desires in some areas.

On the basis of input received at a public meeting held July 8, 1997, the dispose-and-replace alternative was assigned a score of " 2 ," and the recycle alternative was assigned a score of " 5 ."

\subsection{ENVIRONMENTAL IMPACTS}

Disposition alternatives may impact the environment in ways that are not readily reduced (converted) to economic values or health risk numbers. The environmental-impact performance measure addresses potential adverse (or beneficial) impacts on the environment, including physical degradation of surrounding or affected ecological systems and harmful effects on plants and animals. This performance measure is used to assess potential widespread, localized, and long- and short-term impacts on entire ecological systems or constituents. The environmentalimpact performance measure is also used to describe impacts resulting in the loss of use of natural resources such as land or water.

The disposition alternative selected for $59 \mathrm{t}$ of copper ingots is not likely to have a substantial environmental impact on its own; however, because of concern over the incremental effects associated with the disposition of even relatively small amounts of material, environmental impact factors should be considered. The two alternatives (recycle and dispose/replace) are relatively easy to compare because a fair amount of analysis has been completed to assess the relative impacts (Nieves et al. 1995). The dispose-and-replace alternative has impacts above and beyond the recycle alternative that are associated with (1) the disposal of the copper ingots, and (2) the mining and smelting required to produce an amount of copper equivalent to the copper ingots. Information on land disturbance, water quality degradation, air quality degradation, and energy use is provided in the following paragraphs.

\subsubsection{Land Disturbance}

For every ton of copper metal produced, approximately 100 tons of ore must be removed from the earth and processed to remove copper content (Nieves et al. 1995). The unused portion of the ore (gangue) is returned to the earth in a manner designed to minimize impacts; however, inactive mine sites are responsible for acid mine drainage, releases of heavy metals and toxins, and negative impacts on natural habitats. In addition, disposal of the copper ingots would require the use of an additional $1,900 \mathrm{ft}^{3}$ of LLW disposal volume, restricting future land uses associated with that land. 


\subsubsection{Water Quality Degradation}

Acid mine drainage and surface water runoff would be the primary water quality impacts associated with replacement of the $59 \mathrm{t}$ of copper (Nieves et al. 1995).

\subsubsection{Air Quality Degradation}

Air emissions from mining and smelting operations contribute a significant amount of pollutants to the atmosphere. These emissions include both hazardous air pollutants (e.g., As, Cd, $\mathrm{Pb}, \mathrm{Mn}$, and $\mathrm{Ni}$ ), as well as conventional air pollutants (e.g., $\mathrm{NO}_{\mathrm{x}}, \mathrm{SO}_{2}$, volatile organic compounds, and particulates) (Nieves et al. 1995).

\subsubsection{Energy Use}

To produce 1 ton of refined copper wire bar from primary ore requires $128 \times 10^{9} \mathrm{~J}$ of energy. To produce the same 1 ton from recycled No. 2 copper scrap requires $20 \times 10^{9} \mathrm{~J}$ or about $16 \%$ of the amount required to produce from primary ore (DOI 1978). Energy use results in sulfur dioxide and other gaseous emissions from fuel combustion and increases land, air, and water impacts from coal and uranium mining, petroleum extraction, and power generation (Nieves et al. 1995).

A constructed scale is used to assign values to reflect the relative environmental impact of each alternative. The dispose-and-replace alternative is selected as the baseline alternative to which impacts associated with the recycle alternative are compared. The constructed scale values are defined as follows:

- A value of 1 means that the alternative causes two or more of the following to occur: (a) an overall increase in emissions or discharges to any environmental media, (b) an overall increase in injury or destruction of a natural resource, or (c) an overall increase in restriction of future land use;

- A value of 2 means that the alternative causes one of the following to occur: (a) an overall increase in emissions or discharges to any environmental media, (b) an overall increase in injury or destruction of a natural resource, or (c) an overall increase in restriction of future land use;

- A value of 3 means that the alternative results in an overall neutral impact to all of the following: (a) emissions or discharges to any environmental media, (b) injury or destruction of a natural resource, or (c) restriction of future land use;

- A value of 4 means that the alternative causes two or more of the following to occur: (a) an overall decrease in emissions or discharges to any environmental 
media, (b) an overall decrease in injury or destruction of a natural resource, or (c) an overall reduction in restriction of future land use;

- A value of 5 means that the alternative causes two or more of the following to occur: (a) an overall decrease in emissions or discharges to any environmental media, (b) an overall decrease in injury or destruction of a natural resource, or (c) an overall reduction in restriction of future land use.

On the basis of the constructed scale presented, the dispose-and-replace alternative would be assigned a value of " 3 ," and the recycle alternative would be assigned a "5."

Table 14 provides the results of the life cycle analysis phase, as well as the life cycle costs and unit costs. The decision summary matrix provides a convenient form for reviewing and ranking the alternatives. 


\section{PREPARATION PRIOR TO RELEASE}

Certain actions must be completed before the Fernald copper ingots may be released under authorized limits. These actions include following property management procedures, completing any surface treatment or decontamination, and packaging the ingots and staging them for transfer.

\subsection{DOE PROPERTY MANAGEMENT PROCEDURES}

The DOE has established a rigorous protocol for disposition of government property. Property management regulations and procedures that may apply to the disposition of the copper ingots include the following:

- DOE Property Management Regulation (41 CFR Part 109);

- U.S. Department of Energy Acquisition Regulation (DEAR) 945.5, "Management of Government Property in the Possession of Contractors" (41 CFR 945.5);

- DEAR 945.6, "Reporting, Redistribution, and Disposal of Contractor Inventory" (41 CFR 945.6); and

- Fluor Daniel Fernald Procedure SSOP-1044, "Management of Government Property."

The procedures contain documentation and reporting requirements that must be followed. Although the procedures generally provide flexibility in the manner in which property is dispositioned, the selection of certain disposition alternatives may require a justification prior to implementation (e.g., for negotiated sale).

\subsection{SURFACE TREATMENT, DECONTAMINATION, AND PACKAGING FOR TRANSPORT}

Although the copper ingots are proposed to be released on the basis of volumetric or mass-based authorized limits, the ingots may require surface preparation or surface decontamination prior to release to ensure compliance with the site's procedures for release that are based on surface limits. This requirement is consistent with ALARA principles to maintain exposures as low as reasonably achievable. Any required surface decontamination would be conducted during the process of repackaging the ingots for transfer, to eliminate double handling of the material and to save on labor. The ingots would be packaged and staged for transport in accordance with general industry standards for transport of cast copper forms. 


\section{SURVEY AND ANALYSIS METHODS}

Once authorized limits are established, survey or analysis methods (or both) must be employed to verify that the material meets the authorized limits prior to release. Release may use existing survey and analysis results but generally will require verification monitoring prior to release.

\subsection{EXISTING SURVEY AND ANALYSIS RESULTS}

Extensive sampling and analysis work was conducted on the ingots when they were cast in 1980. Total uranium concentration and $235 \mathrm{U}$ enrichments were determined for all of the ingots. The average uranium concentration was determined to be $1.6 \mathrm{ppm}$. The single highest value was determined to be $36 \mathrm{ppm}$. The enrichment ranged between $0.2 \%$ and $1.8 \% 235 \mathrm{U}$ on a total uranium basis. The analytical methods and quality assurance methodology employed during the project are well documented in the standard operating procedures of the FEMP analytical laboratory. The results of this work are summarized in the completion report for the project. These results are also summarized in Section 3 of this document.

In July 1997, one box containing 15 ingots was retrieved from storage at FEMP and opened for radiological survey and visual inspection. The ingots were about 8 in. in diameter and about 30 in. long. The copper ingots were dark in color with white highlighted areas. The discolorations were presumed to be from surface oxidation that formed while the ingots were stored on open pallets in the process area. The oxidation layer was easily removed with a wire brush to expose the underlying copper, which had a bright (new penny) appearance.

Field surveys were completed for fixed plus removable alpha and beta-gamma contamination. Alpha contamination was below the minimum detectable count rate (MDCR) for the field instrument of $600 \mathrm{dpm}$. Beta-gamma contamination ranged from 6,000 to $18,000 \mathrm{dpm} / 100 \mathrm{~cm}^{2}$, with some areas registering very little contamination. Field surveys of areas where the copper was cleaned with the wire brush showed less than the MDCR for fixed plus removable contamination for both alpha and beta-gamma contamination (i.e., less than 600 and $400 \mathrm{dpm}$, respectively).

Smear samples were collected to determine the extent of removable contamination as determined by a low-background proportional counter. Removable alpha contamination ranged from less than the MDCR to $43 \mathrm{dpm} / 100 \mathrm{~cm}^{2}$, and removable beta-gamma contamination ranged from less than the MDCR to $131 \mathrm{dpm} / 100 \mathrm{~cm}^{2}$. The survey results indicate that any measurable surface contamination is bound up with the surface oxidation layer, which appeared to be removed fairly easily.

\subsection{QUALITY ASSURANCE AND QUALITY CONTROL}

Data collection efforts at FEMP are conducted under the auspices of the Sitewide CERCLA Quality Assurance Project Plan (SCQ) (DOE 1994). The SCQ establishes the basis for 
development and execution of data collection and management activities conducted in support of remediation programs. The SCQ endorses the use of the data quality objectives process for ensuring that the right type, quality, and quantity of data are collected to answer the key questions confronting a decision maker. In the present case, the key question to be answered is whether the population of copper ingots meets the authorized release limits requested for approval.

\subsection{SURVEY AND ANALYSIS PRIOR TO RELEASE}

Two data needs must be satisfied by survey or analysis (or both) to verify compliance with the authorized limits prior to release of the copper ingots. First, the ingots must be representatively sampled and analyzed to verify the concentration of uranium determined during the $100 \%$ sampling conducted in support of the original production work. Second, the ingots must be surface-surveyed to demonstrate that decontamination removed loose contamination on the exterior surfaces of the ingots that accumulated while the ingots were in storage. On the basis of results of the surface monitoring, the ingots will require surface decontamination prior to release.

Representative sampling to verify volumetric contamination levels will be completed under a standard sampling plan developed in accordance with the SCQ. On the basis of the variability of uranium concentrations from the production work and the low average uranium concentration, relatively small numbers of randomly collected samples prove adequate to verify, with $95 \%$ confidence, that the ingots comply with the established authorized limits. This verification sampling, along with the results from the production sampling, forms part of the documentation package to support final release of the ingots.

A survey with handheld instrumentation to demonstrate the absence of gross surface contamination will be completed under the FERMCO standard operating procedure following decontamination. Detectable activity of $1,000 \mathrm{dpm} / 100 \mathrm{~cm}^{2}$ for alpha-emitters will be used as the action level. Ingots with surface contamination greater than $1,000 \mathrm{dpm} / 100 \mathrm{~cm}^{2}$ will require surface decontamination prior to packaging for release. Each ingot has approximately $2 \mathrm{ft}^{2}$ of surface area. At a monitoring rate of $1 \mathrm{in} . / \mathrm{s}$, by using a 2 -in. handheld instrument, a single radiation technician can monitor $240 \mathrm{ft}^{2} / \mathrm{h}$. At this rate, a radiation technician can monitor a single ingot in less than one minute.

\subsection{SURVEY AND ANALYSIS DOCUMENTATION}

As part of the FEMP waste analysis plan, a characterization file has been developed for the copper ingots. The file contains the basis for determining the regulatory status of the material, as well as all supporting information and survey and analysis documentation. This characterization file is maintained in the FEMP operating record and is available for review. A summary of the data contained in this package will be provided to prospective bidders on the material before the material is released for recycle. 


\section{STAKEHOLDER COORDINATION}

Stakeholder involvement plays an important role in the development and approval of authorized limits. Involvement is required from public stakeholders, as well as from institutional stakeholders (e.g., DOE, EPA, and NRC or NRC Agreement State). This involvement helps ensure that both technical and social issues have been addressed adequately in light of particular stakeholder concerns and value systems.

The Decision Methodology for Fernald Material Disposition Alternatives (DOE 1997b) provides a framework for addressing both public and institutional stakeholder concerns. The Fernald Site Office and its contractor spent a great deal of time and effort working with stakeholders to develop the decision-making framework. A series of three public workshops were held to obtain input during development and finalization of the methodology. The Ohio Environmental Protection Agency and the U.S. EPA provided comments on the decision methodology, as did individual members of the public.

At the third and final public workshop, which was held on July 8, 1997, a fact sheet on the Fernald copper ingots was distributed, and the project was discussed in the context of the decision methodology. The project drew general support from participants in the meeting. A follow-up meeting was agreed upon to discuss, in general terms, how materials, including but not limited to copper ingots, are released from the Fernald site under authorized surface release limits and volumetric limits. Stakeholder coordination will continue as an ongoing process as the project proceeds through implementation.

Institutional stakeholders include the DOE, state and federal EPA, and the NRC or its Agreement State counterpart. The DOE has authority to approve the development and application of authorized limits. The Ohio Environmental Protection Agency and the U.S. EPA provide input to ensure that the alternative selected is consistent with the remediation plan for the site (e.g., the ROD for a CERCLA site). The NRC or its Agreement State counterpart reviews the proposed authorized limits to ensure that the limits do not trigger a licensing requirement for any parties receiving released materials. Institutional stakeholder coordination will continue throughout review, approval, and implementation of the selected alternative. Records of correspondence with representatives of these agencies may be included as an addendum to this document when they have been completed. 


\section{REFERENCES}

AEC: see U.S. Atomic Energy Commission.

CDA: see Copper Development Association.

Chen, S.-Y., et. al., 1995, “Assessment of Risks and Costs Associated with Transportation of DOE Radioactively Contaminated Carbon Steel," presented at the Recycle 2000 Workshop, sponsored by the U.S. Department of Energy, Office of Environmental Management, Salt Lake City, Utah, Sept. 26-27.

Copper Development Association, 1996a, Copper Facts, publication 9044-1939, New York, N.Y.

Copper Development Association, 1996b, Annual Data 1996: Copper Supply and Consumption 1975-1995, A2001-95/96, New York, N.Y.

DOE: see U.S. Department of Energy.

DOI: see U.S. Department of the Interior.

EPA: see U.S. Environmental Protection Agency.

Garbay, H., et al., 1992, Radiological Impact of Very Slightly Radioactive Copper and Aluminium Recovered from Dismantled Nuclear Facilities, EUR 13160, Commission of the European Communities, Luxembourg.

Institute of Scrap Recycling Industries, 1997, Scrap Specifications Circular 1997, Washington, D.C., Jan. 17.

ISRI: see Institute of Scrap Recycling Industries.

Nabelssi, B.K., et al., 1996, unpublished information, Argonne National Laboratory, Argonne, Ill.

National Lead of Ohio, 1981, Processing CIP/CUP Scrap Copper at FMPC, Phase I Completion Report, Feb. 23.

Nieves, L.A., et al., 1995, Evaluation of Radioactive Scrap Metal Recycling, ANL/EAD/TM-50, Argonne National Laboratory, Argonne, Ill., Dec.

NLO: see National Lead of Ohio.

Population Council, 1997, “Information about the Copper T 380 IUD” [URL http://www.popcouncil/programs]. 
U.S. Atomic Energy Commission, 1974, Termination of Operating Licenses for Nuclear Reactors, Regulatory Guide 1.86, Washington, D.C., June.

U.S. Department of Energy, 1990, "Radiation Protection of the Public and the Environment," Order 5400.5, Feb.

U.S. Department of Energy, 1993, “10 CFR 834: Proposed Rule," Federal Register 58:16268, March 25.

U.S. Department of Energy, 1994, Sitewide CERCLA Quality Assurance Project Plan, FD-1000, prepared by Westinghouse Environmental Management Company of Ohio for the Fernald Environmental Management Project, DOE Fernald Area Office, May.

U.S. Department of Energy, 1996a, Fernald Environmental Management Project 1995 Site Environmental Report, Fernald Area Office, June.

U.S. Department of Energy, 1996b, Operable Unit 3: Record of Decision for Final Remedial Action, Fernald Area Office, Aug.

U.S. Department of Energy, 1996c, Policy on Recycling Radioactively Contaminated Carbon Steel, Office of Environmental Management, Germantown, Md., Sept. 20.

U.S. Department of Energy, 1997a, Draft Handbook for Controlling Release for Reuse or Recycle of Property Containing Residual Radioactive Material, Office of Environmental Management, Germantown, Md., March.

U.S. Department of Energy, 1997b, Decision Methodology for Fernald Material Disposition Alternatives, Fernald, Ohio, May 9.

U.S. Department of the Interior, 1978, Energy Use Patterns for Metal Recycling, Information Circular 8781, Bureau of Mines, Washington, D.C.

U.S. Environmental Protection Agency, 1991, "40 CFR Parts 141 and 142, Drinking Water Regulations: Maximum Contaminant Level Goals and National Primary Drinking Water Regulations for Lead and Copper," Federal Register 56:26460, Jan. 
APPENDIX:

OVERVIEW OF SECONDARY COPPER INDUSTRY 


\section{APPENDIX:}

\section{OVERVIEW OF SECONDARY COPPER INDUSTRY}

Authorized limits are derived on the basis of analysis of release alternatives to ensure that radiation exposures resulting from release are as low as reasonably achievable (ALARA) and below acceptable limits. Development of credible release alternatives, therefore, is predicated on understanding how the property will be handled once released into the public domain.

To develop the actual and worst plausible realistic release alternatives for the Fernald copper ingots, a detailed understanding of the secondary copper industry is necessary. Important factors for evaluating potential impacts from release alternatives include the flow of scrap and refined copper within the copper industry, the production processes used to refine scrap copper for reuse, the disposition of waste streams generated from processing, the end-use products made from refined copper, and the life cycle of copper products in commerce.

Copper is one of the first metals to have been used by mankind and has been in continuous use for over 6,000 years. Archaeologists have recovered a portion of a water plumbing system from the pyramid of Cheops in Egypt that is still in serviceable condition. A museum at the University of Pennsylvania displays a copper frying pan that has been dated to more than 5,000 years old. Because few of its uses are dissipative in nature, copper has an excellent potential for recovery. The copper industry takes advantage of this fact, using scrap copper to meet nearly half of its annual production needs.

Section A.1 summarizes how materials move through the copper industry. This section identifies the types of copper products in commerce and how they are distributed in end-use applications. The section characterizes the life cycle of copper products and discusses factors that influence the decision to recycle copper at the end of the useful product life. Section A.1 also explains how scrap copper enters and moves through the copper industry along with refined copper. This materials-oriented view of the industry is important for selecting the most appropriate release alternatives for evaluation.

Section A. 2 describes the production processes used in the recycling of scrap copper. This section follows the process in a logical stepwise fashion, covering scrap processing, smelting, refining, semifabrication of copper forms, and manufacturing of end-use products. This process-oriented view of the industry is important for identifying input parameters to complete the dose assessment, cost estimates, and ALARA analysis for the alternatives being evaluated.

\section{A.1 COPPER MATERIALS IN COMMERCE}

The physical properties of copper, including its malleability and workability, its corrosion resistance and durability, its high electrical and thermal conductivity, and its ability to alloy with other metals, have made it an important metal to a number of diverse industries. Copper plays an important role in building construction, electrical and electronic products, transportation 
equipment, industrial machinery and equipment, and consumer and general products. Table A.1 summarizes consumption of copper products in these major end-use markets.

Building construction accounts for $40 \%$ of all copper use. Residential construction is about two-thirds of the building construction market. The average single-family home in the United States is about $2,100 \mathrm{ft}^{2}$ and uses $200 \mathrm{~kg}(439 \mathrm{lb})$ of copper. Of this amount, $44 \%$ is comprised of building wire, and $40 \%$ is comprised of plumbing tube, fittings, valves, and plumbers' brass goods. The remaining $16 \%$ is included in built-in appliances, builders' hardware, and miscellaneous wire and tube.

Consumer and general products account for about $10 \%$ of copper consumption. Consumers are not intimately exposed to the contained copper in many products; for example, the copper within appliances, consumer electronics, and electrical cord sets is generally inaccessible. The consumer is in more intimate contact with the contained copper in certain products. Examples of some of the most intimate uses include copper contained in flatware (forks, knives, and spoons), cooking pots and pans, brass musical instruments, jewelry and coinage, surgical instruments, and medical devices (e.g., intrauterine device [IUD] for contraception). Most silver-plated flatware has a copper-zinc-nickel alloy base (nickel-silver) over which silver is plated. Sterling silver flatware generally contains $7.5 \%$ copper alloyed with

TABLE A.1 U.S. Consumption of Copper Products by Major End-Use Market in 1994

\begin{tabular}{lll}
\hline \multicolumn{1}{c}{ End-Use Market } & $\begin{array}{c}\text { Metal } \\
\text { Content } \\
\left(10^{3} \text { t) }\right.\end{array}$ & $\begin{array}{c}\text { Percent } \\
\text { of Total }\end{array}$ \\
\hline $\begin{array}{l}\text { Building construction: building wiring; plumbing and heating; air } \\
\text { conditioning and commercial refrigeration; builders' hardware; } \\
\text { architectural }\end{array}$ & 1,360 & 40 \\
$\begin{array}{l}\text { Electrical and electronics products: power utilities; telecommuni- } \\
\text { cations; business electronics; lighting and wiring devices }\end{array}$ & 862 & 25 \\
$\begin{array}{l}\text { Industrial machinery and equipment: in-plant equipment; industrial } \\
\text { valves and fittings; nonelectrical instruments; off-highway vehicles; } \\
\text { heat exchangers }\end{array}$ & 410 & 12 \\
$\begin{array}{l}\text { Transportation equipment: automobile, truck, and bus; railroad; } \\
\text { marine; aircraft and aerospace }\end{array}$ & 435 & 13 \\
$\begin{array}{l}\text { Consumer and general products: appliances; cord sets; military and } \\
\text { commercial ordnance; consumer electronics; fasteners and closures; } \\
\text { coinage; utensils and cutlery; miscellaneous }\end{array}$ & 353 \\
\begin{tabular}{l} 
Total consumption \\
\hline
\end{tabular} & & 10 \\
\hline
\end{tabular}


92.5\% silver, making the metal hard and sturdy. A copper frying pan may contain up to $2.3 \mathrm{~kg}$ $(5 \mathrm{lb})$ of copper. A typical musical instrument (trumpet) has a mass of about $1 \mathrm{~kg}(2.2 \mathrm{lb})$. A good example of copper jewelry is the copper bracelets commonly produced in the southwestern United States; each bracelet contains about $71 \mathrm{~g}(2.5 \mathrm{oz})$. Finally, the copper T 380 IUD contains about $0.2 \mathrm{~g}$ of copper.

Table A.2 summarizes the supply of copper products from wire mills, brass mills, foundries, and powder plants that are manufactured into end-use products. These plants supply the semifabricated copper to manufacturing facilities producing end-use equipment and goods. Nearly half of all copper (48\%) is consumed as wire for electrical applications across multiple end-use markets. Much of the remainder (45\%) ends up in copper alloy products produced at brass mills. Copper alloys have a wide range of uses across the end-use markets, including valves and fittings, heat exchangers, automobile radiators, and decorative brasses, among others.

Copper may be used in its unalloyed form or may be alloyed with zinc, tin, or other metals to form brass, bronze, or other copper alloys. Over 370 recognized coppers and copper alloys are produced and used in the United States. In 1994, about $43 \%$ of the copper ended up in copper alloys. The major families of copper and copper alloys include coppers, high-copper alloys, brasses, bronzes, copper-nickels, copper-nickel-zinc alloys, leaded coppers, and special alloys. Within these families, a standard designation system has been developed to delineate particular coppers or alloys on the basis of their chemical composition (e.g., copper No. C27400, yellow brass, 63\%) (CDA 1985). The Standards Handbook (CDA 1985) also identifies typical uses for each copper or copper alloy listed (e.g., copper No. C27400 used for plumbing accessories and traps).

\section{A.1.1 Life Cycle of Copper Products}

The availability of scrap copper depends on the expected life of the copper-containing product, the quantity and quality of copper contained in the product, and the ease with which the copper can be separated and reclaimed from the product. According to one study, the useful life of electrical plants and machinery averages 30 years; in nonelectrical machinery, 15 years; in housing, 35 years; in transportation, 10 years; and in all other end-use sectors, about 10 years. The expected life of the copper-containing product drives the turnover rate and influences how much copper will be in circulation in useful products. The quality and quantity of copper contained in an end-use product, combined with the ease of recovery, generally determine whether reclamation is cost-effective relative to producing copper from ore.

The copper that remains in circulation in useful and used products is referred to as the "reservoir" of available scrap. One estimate puts the current world reservoir of copper in circulation in products at over 300 million t (more than 175 times the current annual world production of copper from ore). Although not all of this material is readily available for recovery, the estimate is indicative of the relative size of the potential recycle pool. 
TABLE A.2 U.S. Supply of Products from Wire Mills, Brass Mills, Foundries, and Powder Plants

\begin{tabular}{lccc}
\hline & $\begin{array}{c}\text { Metal } \\
\text { Content } \\
\left(10^{3} \text { t }\right)\end{array}$ & $\begin{array}{c}\text { Percent } \\
\text { of This } \\
\text { Segment }\end{array}$ & $\begin{array}{c}\text { Percent } \\
\text { of All } \\
\text { Segments }\end{array}$ \\
\hline Wire-mill products & & & \\
Bare wire & 100 & 6 & 3 \\
Telecommunications cable & 211 & 13 & 6 \\
Electronic wire and cable & 110 & 7 & 3 \\
Building wire & 518 & 32 & 15 \\
Magnet wire & 304 & 19 & 9 \\
Power cable & 137 & 8 & 4 \\
Apparatus wire and cordage & 106 & 6 & 3 \\
Automotive wire and cable & 117 & 7 & 3 \\
Other insulated wire and cable & 39 & 2 & 1 \\
Total & & & \\
Brass-mill products & 1,642 & 100 & 47 \\
Strip, sheet, plate, and foil & & & \\
Mechanical wire & 527 & 34 & 16 \\
Rod and bar & 31 & 2 & 1 \\
Plumbing tube and pipe & 486 & 32 & 14 \\
Commercial tube and pipe & 272 & 18 & 8 \\
Total & 225 & 15 & 7 \\
Foundry products & & & \\
Powder-mill products & 1,541 & 101 & 46 \\
Total of all segments & 195 & 100 & 6 \\
\hline & & & \\
& 21 & 100 & 1 \\
\hline
\end{tabular}

a Not applicable. 


\section{A.1.2 Flow of Refined and Scrap Copper in the Copper Industry}

Refined copper is generally either extracted and refined from copper ores (primary copper) or recycled from scrap (secondary copper). Primary copper processes include mining, milling, concentrating, leaching, solvent extraction and electrowinning, smelting, refining, production of semifabricated forms, and manufacturing of end-use products. Secondary copper processing starts with scrap preparation, with appropriate grades of scrap inserted into primary copper processes at the smelting, refining, or semifabrication steps. Figure A.1 illustrates the flow of refined and scrap copper through the processing steps.

Scrap processed as secondary copper may be generated from either manufacturing processes ("new scrap) or from end-use applications ("old scrap"). Consumption of copper scrap accounts for nearly $41 \%$ of domestic consumption of copper. Table A.3 breaks down the consumption into uses by percentages.

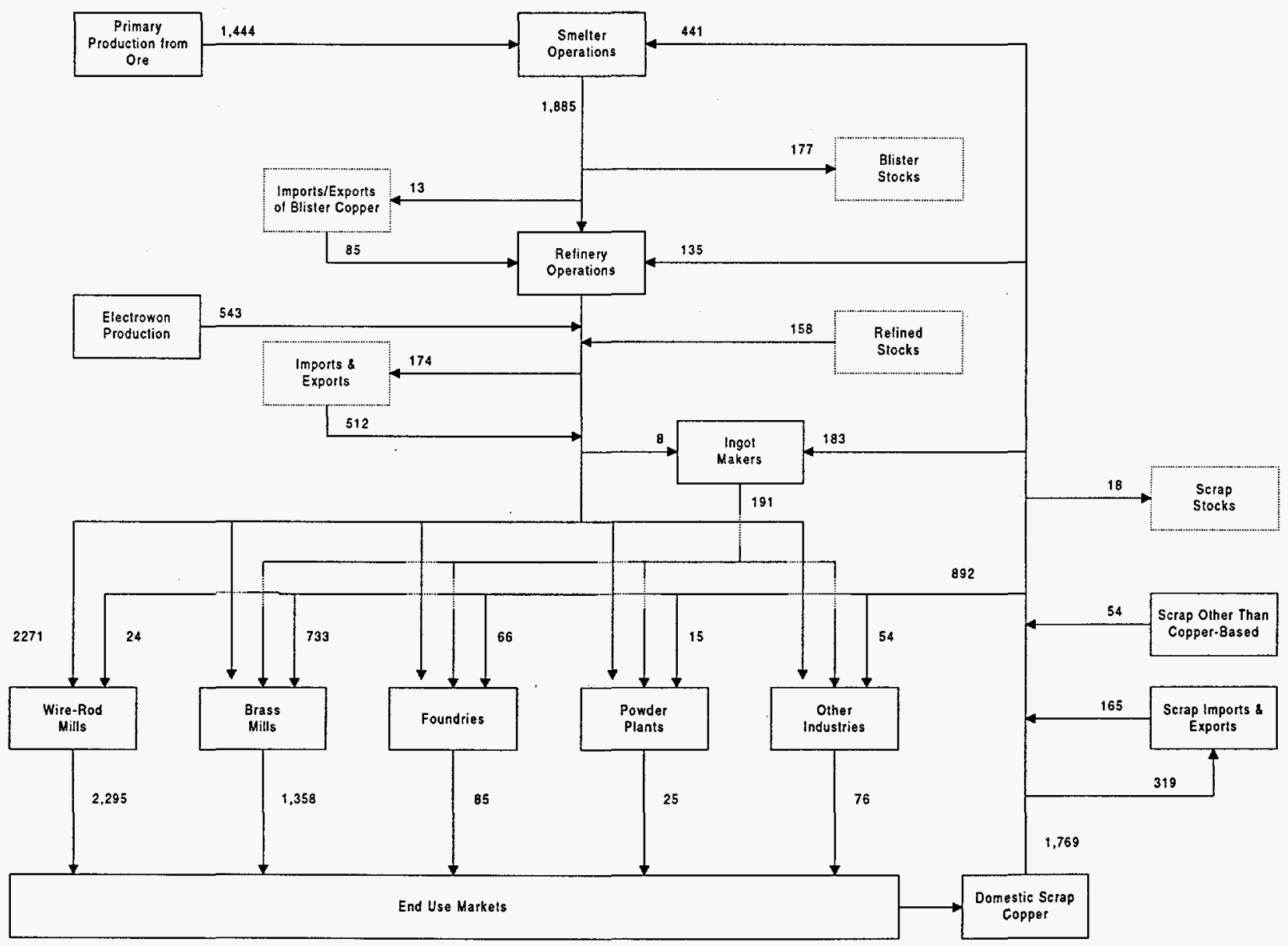

FIGURE A.1 Flow of Copper Scrap and Refined Copper in the United States (in thousands of tonnes [metric tons]) 
TABLE A.3 U.S. Consumption of Copper from Ore and Scrap in 1994

\begin{tabular}{lrrr}
\hline \multicolumn{1}{c}{ Item } & $\begin{array}{c}\text { Consumption } \\
\left(10^{3} \mathrm{t}\right)\end{array}$ & $\begin{array}{c}\text { Percent } \\
\text { of Subtotal }\end{array}$ & $\begin{array}{r}\text { Percent } \\
\text { of Total }\end{array}$ \\
\hline Copper cathodes from ore treatment & & & \\
$\quad$ Refined production & 1,444 & 73 & 40 \\
$\quad$ Electrowon production & 543 & 27 & 15 \\
Total & 1,987 & $-\mathrm{a}$ & 55 \\
& & & \\
Refined copper from scrap by & & & 12 \\
$\quad$ Smelters & 135 & 77 & 4 \\
$\quad$ Electrolytic and fire refiners & 576 & - & 16 \\
Total & & & \\
& 183 & 17 & 5 \\
Direct recovery from scrap by & 733 & 68 & 20 \\
Ingot makers & 66 & 6 & 2 \\
Brass mills & 93 & 9 & 3 \\
Foundries & 1,075 & - & 30 \\
Other miscellaneous industries & & & 100 \\
Total & 3,638 & - & \\
Total copper consumption in all & & & \\
forms & & & \\
\hline
\end{tabular}

a Not applicable.

For a candidate population of scrap copper for recycling, the grade of the scrap is the single most significant factor that determines the type of facility to which the scrap will be sent for recovery. Ideally, scrap is reintroduced into the production process so as to increase, rather than degrade, copper purity or desirable alloy characteristics. Essentially all low-grade residues are reclaimed at smelter facilities. Nearly $60 \%$ of the No. 1 scrap copper is melted at brass mills (without any prior smelting or refining) to make copper alloy products; No. 2 scrap is consumed at smelter and refinery operations. About $93 \%$ of the leaded yellow brass is recycled at brass mills to produce more brass product. New scrap tends to have less contaminants and a better pedigree (confidence in its composition) than old scrap and therefore commands higher prices in the secondary copper market. Table A.4 shows the general grade of scrap processed at the different steps of the copper production process.

Scrap copper is classified (graded) to facilitate its commercial transfer within the industry. The Institute of Scrap Recycling Industries (ISRD), for example, identifies 45 individual grades of scrap copper. These grades include copper and copper alloy scrap. Overall, these 45 grades are aggregated into 11 of the most common grades of copper scrap designated by ISRI (1997). 
TABLE A.4 Consumption of Scrap Copper at U.S. Processing Facilities by Grade

\begin{tabular}{|c|c|c|c|c|c|c|c|c|c|}
\hline \multirow[b]{2}{*}{ Scrap Copper Grade } & \multicolumn{9}{|c|}{ Consumption of Scrap Copper $\left(10^{3} t\right)$} \\
\hline & Total & Smelter & Refinery & $\begin{array}{c}\text { Ingot } \\
\text { Maker }\end{array}$ & $\begin{array}{c}\text { Wire-Rod } \\
\text { Mill }\end{array}$ & $\begin{array}{c}\text { Brass } \\
\text { Mill } \\
\end{array}$ & Foundry & $\begin{array}{c}\text { Powder } \\
\text { Plants } \\
\end{array}$ & $\begin{array}{c}\text { Other } \\
\text { Industries }\end{array}$ \\
\hline No. 1 wire and heavy & 514 & $-a$ & - & 151 & 24 & 305 & - & 15 & 19 \\
\hline No. 2 mixed heavy and light & 361 & 144 & 135 & 32 & - & 46 & 4 & - & - \\
\hline Red brass & 62 & 41 & - & - & - & 8 & 13 & - & - \\
\hline Leaded yellow brass & 381 & 25 & - & - & - & 354 & 2 & - & - \\
\hline Yellow and low brass & 74 & 7 & - & - & - & 24 & 8 & - & 35 \\
\hline Cartridge cases and brass & 61 & 15 & - & - & - & 46 & - & - & - \\
\hline Auto radiators & 71 & 65 & - & - & - & - & 6 & - & - \\
\hline Bronzes & 24 & 13 & - & - & - & - & 11 & - & - \\
\hline Nickel-copper alloys & 22 & - & - & - & - & - & 22 & - & - \\
\hline Low grade and residues & 81 & 81 & - & - & - & - & - & - & - \\
\hline Other alloy scrap & 57 & 50 & - & - & - & 7 & - & - & - \\
\hline Total scrap & 1,708 & 441 & 135 & 183 & 24 & 792 & 66 & 15 & 54 \\
\hline Total alloyed scrap & 833 & 297 & - & - & - & 441 & 62 & - & 35 \\
\hline Total unalloyed scrap & 875 & 144 & 135 & 183 & 24 & 351 & 4 & 15 & 19 \\
\hline
\end{tabular}

a None reported. 


\section{A.2 SECONDARY COPPER PROCESSING}

Five basic steps are involved in scrap copper processing: (1) scrap preparation (grading, sorting, and sizing); (2) smelting (smelting and converting); (3) refining (fire refining and electrorefining); (4) production of semifabricated forms (casting, hot working, cold working, and annealing); and (5) manufacturing end-use products (cold forming, hot and cold forging, machining, joining, and electrodeposition). Depending on classification, scrap copper will require processing by some or all of these steps.

Scrap copper is generally transferred in commerce by scrap metal brokers. Scrap brokers grade, sort, size, and bale scrap for transfer and use in the industry. This process may occur at the location where the scrap is generated or may occur at the broker's scrap yard. Scrap yards may also use mechanical separation systems or incinerators to remove insulation from copper wire or perform other gross physical separations. Scrap may be transferred directly from point of generation to the recovery facility without physically stopping at a scrap yard.

Smelters and refineries convert scrap copper into metal of sufficiently high chemical purity for downstream uses. During 1994, eight primary and five secondary smelters and nine electrolytic and six fire refineries operated in the United States. Three of the electrolytic refineries were dedicated facilities associated with secondary smelters and mostly processed anode copper derived from scrap. Several of the refineries that mainly processed primary anode copper purchased or tolled some anode copper derived from scrap. All of the fire refineries processed copper scrap.

Ingot makers, brass mills, wire-rod mills, foundries, manufacturers, and chemical plants use the refined copper to produce semifabricated forms for manufacturing end-use products. In 1994, copper was consumed, both as refined copper and as direct melt scrap, at 35 brass mills, 15 wire-rod mills, and 600 foundries, chemical plants, and miscellaneous consumers.

\section{A.2.1 Scrap Preparation}

Sorting, grading, and rough sizing are generally accomplished by using shears and grapples attached to hydraulically powered arms of heavy equipment. Much of scrap grading is done by sight by experienced scrap-yard workers. Some scrap metal items require specific preparation; for example, copper wire generally must be separated from motor casings and rotors. Likewise, copper wire may require separation from plastic insulation by mechanical means (e.g., shredding or granulating, followed by air separation) or by thermal means (e.g., burning in an incinerator or box furnace). Thermal separation is less frequently practiced now because of air emission concerns.

Scrap brokers may pick up scrap at a generating facility or accept scrap delivered to their facility. Scrap brokers generally arrange for transportation to their customers. Scrap may be stored at scrap yards pending sale and transfer, but generally scrap inventories are turned over fairly quickly. 


\section{A.2.2 Smelting Operations}

Low-grade scrap copper is generally refined in a two-step process, first being smelted to produce a black copper matte and then further purified in a second furnace to produce a rough copper product. Typical smelter and converter furnace conditions are described below (Biswas and Davenport 1980).

\section{A.2.2.1 Smelting}

The primary smelting unit for low-grade scrap is the scrap blast furnace. Typical dimensions are 1-3 m wide, 2-6 m long, and 3-5 m high. The scrap is blended to give a mixed charge on the order of $30 \%$ copper (about the same as primary concentrate smelting). Coke is added with the charge at a rate of $80-120 \mathrm{~kg} / \mathrm{ton}$ of scrap, and silica and iron are added to produce slag with a low melting point. Organic materials are burnt off the scrap prior to blastfurnace smelting to avoid fouling the stack and dust-control system.

The product of the blast furnace is liquid black copper $(70-85 \% \mathrm{Cu}$ and $2-5 \% \mathrm{Fe}$, plus other scrap impurities). Scrap blast furnaces can produce 10-20 tons of black copper per square meter of hearth per day (100-300 tons/d). The furnace is operated to oxidize unwanted metals (aluminum, iron, and zinc). As a result, the copper contents of scrap blast-furnace slags are relatively high $(1-2 \% \mathrm{Cu})$. Blast-furnace slag is generally sent for disposal. Zinc-bearing fume ( $50 \%$ zinc) from the fume-collection system may be sold for zinc recovery.

\section{A.2.2.2 Converter Furnace}

Black copper from the blast furnace is usually refined in small $(2 \mathrm{~m}$ in diameter and $3 \mathrm{~m}$ long) Pierce-Smith converters. The converter is mounted to rotate on its horizontal axis. Molten matte from smelting is charged to the converter through a large opening (mouth), and air is blown into the matte via tuyeres along the length of the vessel. The molten copper is maintained at $1,150-1,200^{\circ} \mathrm{C}$. Silica flux is added gradually to slag off the iron and impurities as they are oxidized. At the end of the slagging period, the converter is rotated, and the slag is skimmed out of the mouth. The copper is then air-blown again, and the molten copper is poured off into a ladle by rotating the converter.

The product of the converter is $96-97 \%$ rough copper. Pierce-Smith converters can process 30-40 tons of molten matte per batch, and each batch takes from 3 to 12 hours to complete. Slag from the converter, containing 30-40\% copper, is recycled to the blast furnace for recovery of copper content. Tin-bearing fume from the fume-collection system is collected and sold for tin recovery. 


\section{A.2.3 Refining}

Copper from scrap smelting and converting is generally given a final oxidation treatment in a fire-refining or anode furnace and cast into electrodes for electrorefining. The copper is then generally electrorefined to remove low levels of impurities, such as nickel and lead, commonly found in scrap copper.

\section{A.2.3.1 Fire Refining}

Fire refining is used to remove sulfur and to reduce oxygen content. Rough copper is fed to a reverbatory or rotary furnace. Batch sizes run from 150 to 400 tons of rough copper. Oil or natural gas is used heat the charge. When liquid rough copper is fed, a batch requires from 8 to 10 hours to complete; and when the charge is solid copper, a period of 20-22 hours is required. Air is forced through the charge, oxidizing any sulfur to generally less than $0.003 \%$. Oxygen content is then reduced by either injecting hydrocarbon gas (methane, propane, or refinery gas) or by "poling" (inserting green wood poles below the surface of the melt). Oxygen content is reduced from $0.7 \%$ to generally less than $0.05 \%$. Dross from the furnace is recycled to the smelter for copper recovery. Fire-refined copper is either cast into anodes for treatment in an electrolytic refinery to produce electrical-grade copper or cast into other shapes for semifabrication of mechanical-grade products.

\section{A.2.3.2 Electrorefining}

Electrorefining is used to increase copper purity to greater than $99.99 \%$. The main equipment in the refinery tankhouse are the 500 to 2,000 cells constructed of wood or concrete, each $5 \mathrm{~m}$ long by $1 \mathrm{~m}$ wide by $1.2 \mathrm{~m}$ deep. Each cell takes $36 / 42$ anodes and 37/43 cathode starter sheets. The anodes are spaced at $100-\mathrm{mm}$ intervals, connected in parallel to a bus bar that runs on the edge of the cell. The starter sheets are interposed, likewise connected in parallel to a bus bar running on the edge of the cell. Individual cells are then connected in series. The starter sheets are thin (1-mm) plates of pure copper, with a surface area slightly larger than the anodes, with a mass of about $5 \mathrm{~kg}$ each. The anodes are $1 \mathrm{~m}^{2}$ by $30-50 \mathrm{~mm}$ thick, with a composition as described above.

The basic process involves the electrolytic solution of copper from the anodes and redeposition on the cathodes in sulfuric acid/copper sulfate electrolyte solution. Free sulfuric acid content is controlled at $12-20 \%$, and copper content is held around 3-5\%. Small quantities of leveling agents to improve copper deposition and of sodium chloride $(0.004 \%)$ to precipitate specific impurities are added to the solution. Voltage across the cell ranges from 0.18 to $0.45 \mathrm{~V}$, with an average of $0.23 \mathrm{~V}$. The precious metals, which are electropositive to copper, are soluble in the electrolyte, with the exception of silver. Silver is precipitated as chloride and settles with the "slimes" that contain the gold and platinum group metals. The metals in the anode that are electronegative to copper are not deposited and either precipitate along with the slime or remain in solution. During processing, a portion of the electrolyte is removed for purification and temperature control of the cells. 
Cathodes are withdrawn via overhead cranes when they reach 100 to $120 \mathrm{~kg}$, and new starter cathodes are inserted. The cathodes take up to 24 days to reach this size. Removed cathodes are washed, dried, and dispatched. When $85-90 \%$ of the original anode weight has been transferred, the anode "stubs" are removed and remelted in the anode furnace. When the cathodes are withdrawn, the slimes that have accumulated in the bottom of the cells are removed via a launder to holding pits for pumping to the recovery plant where precious metals are recovered. Typical production capacities are between 100 and 500 tons/d.

\section{A.2.4 Production of Semifabricated Forms}

Various melting operations are used in producing semifabricated copper forms. For highconductivity copper, generally only copper cathodes from primary copper production are melted, with precautions to avoid contamination, particularly for constituents that have deleterious effects on electrical properties. Reverbatory furnaces, operated in the batch mode, are used for large castings. Shaft furnaces may be used to produce a continuous flow of metal to holding furnaces or direct to molds for wire bar or ingots. Electric arc melting may also be employed for melting alloys to reduce the risk of contamination. Crucible furnaces, heated by gas or oil, are widely used for brass and bronze, particularly in foundries for die or sand casting.

\section{A.2.4.1 Casting}

Casting is used either to form final shapes or to form ingots or billets for further processing. Sand casting is used for shapes with a variety of complexity and having a mass of from less than $1 \mathrm{~kg}$ to several metric tons. Die casting is used for some of the copper alloys, particularly certain brasses and aluminum bronzes, to give close accuracy, excellent surface finishes, and superior mechanical properties. Most copper is cast into horizontal, open wire bar molds that generally have a trapezoidal cross section and tapered ends to facilitate heavy reductions during hot rolling. Depending on the metal, casting is conducted at melt temperatures between $1,000^{\circ} \mathrm{C}$ and $1,200^{\circ} \mathrm{C}$.

\section{A.2.4.2 Hot Working}

Hot working involves deformation of copper and its alloys above their recrystallization temperatures. This step is commonly used in the production of finished shapes and semifabricated forms. Hot-working operations include rolling, extrusion and piercing, forging, and pressing at temperatures ranging from about $700^{\circ} \mathrm{C}$ to $1,000^{\circ} \mathrm{C}$. Prior to hot working, slabs for rolling and billets for extrusion may require scalping or machining to remove surface defects that would otherwise persist in the finished product. All copper-based materials that have been hot worked must be descaled by pickling (e.g., by immersion in a $5-10 \%$ sulfuric acid bath at $\left.80^{\circ} \mathrm{C}\right)$. 


\section{A.2.4.3 Cold Working and Annealing}

Cold working and annealing are used to produce final product shapes such as copper strip, rod, sheet, foil, and wire. Cold working increases metal hardness, and therefore interstage annealing steps are often required to resoften the metal. Annealing is accomplished by prolonged heating at temperatures ranging from about $200^{\circ} \mathrm{C}$ to $850^{\circ} \mathrm{C}$.

\section{A.2.5 Manufacturing Processes}

Conversion of the semifabricated forms of copper and copper alloys to finished components and assemblies may involve any of the usual processes used by manufacturing industries. These processes include cold forming, hot and cold forging, joining, machining, and electrodeposition. Items manufactured by these processes may vary widely, from wire with less than a 1-mm diameter to major components for a heavy chemical plant. These items are then incorporated into end-use products for wholesale and retail distribution.

\section{A.3 REFERENCES}

Biswas, A.K., and W.G. Davenport, 1980, Extractive Metallurgy of Copper, Pergamon Press, New York, N.Y., 1980.

CDA: see Copper Development Association.

Copper Development Association, 1985, Standards Handbook: Wrought and Cast Copper and Copper Alloy Products, New York, N.Y.

Institute of Scrap Recycling Industries, 1997, Scrap Specifications Circular 1997, Washington, D.C., Jan. 17.

ISRI: see Institute of Scrap Recycling Industries. 